\title{
CARNAVALIZAÇÃO DA POLÍTICA OU POLITIZAÇÃO DO CARNAVAL: CARNAVAL CARIOCA POR MEIO DAS CHARGES (1930-1937)
}

\author{
Alberto Gawryszewski ${ }^{1}$
}

Resumo: O objetivo deste texto é demonstrar como a charge, relacionada ao tema do carnaval, pode ser um importante instrumento de compreensão de um momento histórico. No caso, o recorte temporal é entre 1930 e 1937 e o recorte espacial é a cidade do Rio de Janeiro. As imagens foram retiradas de duas importantes revistas brasileiras: O Malho e Careta.

Palavras-chave: Cidade do Rio de Janeiro; Cartoons; Imprensa: Pedro Ernesto; "revolução" de 30

\section{CARNIVALIZATION OF POLITICS OR POLITICIZATION OF CARNIVAL? CARTOONS AND CARNIVAL “CARIOCA” (1930-1937)}

\begin{abstract}
The objective of this text is to show how cartoons related to the theme of carnival can be an important tool to understand a historic time. In this case, the period is from 1930 to 1937 and the place is Rio de Janeiro City. Images were taken from two important brazilian magazines: $O$ Malho and Careta.
\end{abstract}

Keywords: City of Rio de Janeiro; Cartoons; Press: Pedro Ernesto; "revolution" of 30

\section{CARNAVALIZACIÓN DE LA POLÍTICA O POLITIZACIÓN DEL CARNAVAL: CARNAVAL CARIOCA POR MEDIO DE LAS CARICATURAS (1930-1937)}

Resumen: El objetivo del texto es demostrar cómo las caricaturas, relacionada al tema del carnaval, puede ser un importante instrumento de comprensión de un momento histórico. En el caso, el recorte temporal es entre 1930 y 1937 y el recorte espacial es la ciudad de Río de Janeiro. Las imágenes fueron retiradas de dos importantes revistas brasileñas: El Malho y Careta.

Palabras clave: Ciudad de Río de Janeiro; Cartoons; Prensa: Pedro Ernesto; "revolución" de 30 .

\section{INTRODUÇÃO}

Este texto visa a apresentar as charges presentes nas revistas ilustradas de humor $O$ Malho e Careta, ambas publicadas na cidade do Rio de Janeiro. A escolha dessas revistas se deve ao fato de que as mesmas tinham grande tiragem, circulação nacional e se dirigiam a um público da classe média e alta brasileira. O recorte temporal (1930-1937) escolhido está voltado

\footnotetext{
${ }^{1}$ Doutor em História Econômica pela Universidade de São Paulo (1996); Pós-doutorado em História Social pela Universidade Federal do Rio de Janeiro (2004); Pós-doutorado em História pela Universidade Federal Fluminense (2013). Professor Associado do Departamento de História da Universidade Estadual de Londrina.
} 
principalmente para a administração do prefeito Pedro Ernesto (1931-1936), quando se oficializou o carnaval carioca no calendário turístico da prefeitura.

A caricatura/charge seria o carnaval ilustrado? Quais as relações entre o novo regime político que se instaura no país em 1930 e essa nova postura com o carnaval popular? A charge política e a de humor, com seus traços e diálogos, podem nos ajudar a compreender o período em questão? Assim, a seleção das charges utilizadas está dentro dos objetivos deste texto, ou seja, compreender a relação do carnaval e política por meio da charge e do riso. A charge é vista como um importante instrumento de construção de uma visão crítica do mundo pelo artista do traço.

A revista Careta é, hoje, uma das publicações mais usadas pelos pesquisadores brasileiros como fonte de pesquisa. Muitas razões existem para isso, seja a facilidade de encontrá-la completa (em Bibliotecas, no formato impresso, ou em sites, no formato digital), seja pela sua longevidade (52 anos ininterruptos), e pela grande quantidade de imagens contidas (fotografias, charges, caricaturas e propagandas) e textos.

Careta foi lançada em 1908 na cidade do Rio de Janeiro, em um momento distinto de nossa história e da história da imprensa. A cidade carioca tinha passado por profundas transformações urbanísticas e arquitetônicas na perspectiva de mostrar ao mundo um novo Brasil, mais dinâmico e moderno. Careta fazia parte desse novo mundo, dividindo espaço com outras publicações ilustradas (em especial $O$ Malho), que também surgiram nesse período. $\mathrm{O}$ desenvolvimento de novas técnicas de impressão, que possibilitava a inclusão de imagens, até em cores, e grandes tiragens, levou ao barateamento do valor unitário das publicações e à capacidade de atingir um público inédito e variado, tanto local como nacional e internacional. Além da grande tiragem possível, a expansão da propaganda - com uso de imagens e diversos formatos de fontes - ajudou na arrecadação monetária para as revistas, dando um caráter profissional e permanente aos seus colaboradores.

Fundado pelo empresário Jorge Schmidt, ex-diretor e fundador de outras revistas ilustradas, Careta era um semanário (saía aos sábados), com cerca de 40 páginas, e tinha um caráter eminentemente comercial, como dito no próprio editorial de abertura: "Todavia, nossa esperança é justamente que o público morra pela Careta, a fim de que ela viva. E, feita cinicamente essa confissão egoísta [...]”. Ainda conforme este: “[...] Careta é feita para o público, o grande e respeitável público, com P maiúsculo!" (Careta Ano I, nº 01, 06/06/1908, p.03). Este seria um público seleto, formador de opinião, intelectual e refinado, mas não se quer 
dizer que seu alvo também não fosse a população mais humilde. As charges e caricaturas coloridas em sua capa, a qualidade gráfica, as colunas variadas (criadas no decorrer do tempo), repletas ou não de fotografias (de festas, bailes, esportes, solenidades, etc.), caricaturas, charges, charadas, tiradas de humor, etc., atraíam um público maior do que a elite financeira e intelectual, seja pelo acesso direto pela compra, seja pelo acesso indireto em locais públicos (barbearias, engraxatarias, etc.). Portanto, o alcance da revista Careta foi extraordinário para o período de sua existência. Deve-se dar destaque ao fato de que a maioria da população brasileira era analfabeta e, assim, as imagens possuíam potencial de atração e, também, de uma interpretação diferenciada.

Se no início a proposta da Careta era unicamente fazer "caretas", isso foi mudado no decorrer do tempo, em especial a partir de 1930, quando a situação política a exigiu menos humorística. Na realidade, o debate político, econômico e social do país adquiriu um maior papel em seu conteúdo, incluindo o uso da charge e da caricatura nesse viés.

Em um editorial de 1953, Careta escreveu: “[...] fomos anti-revolucionários em 1930 como em 32; em 1935 como em 45 e se-lo-emos hoje como amanhã. Do mesmo modo, somos anti-comunistas pelos mesmos motivos por que somos anti-facistas e anti-nazistas, e porque somos anti-franquistas, anti-peronistas e anti-getulistas" (Careta, 01-04-1953, p. 03). Assim, Careta nunca foi imparcial, promovendo debates sob sua ótica sobre o que estava ocorrendo no país nas áreas econômica, social e, especialmente, política.

A revista $O$ Malho foi fundada em setembro de 1902 por Luis Bartolomeu de Souza e Silva. Aqui praticamente se poderiam repetir as linhas pretéritas sobre Careta. Segundo Tenório (2009), seu fundador era mais um intelectual desiludido com a república implantada, inclusive sendo preso por defender prisioneiros políticos da revolta da Armada (1893) em artigos de jornais. Era composta de várias seções, com muitas charges, fotografias e artigos. Seu público leitor seria amplo, atingindo desde a classe operária desqualificada até uma classe mais favorecida financeiramente. Tal qual a revista Careta, O Malho teve vida longa, 52 anos (1902 a 1954).

Seu título nos remete à expressão "malhar", que significaria acentuar aspecto negativo (geralmente) uma pessoa ou coisa por meio da zombaria. Sendo a charge originalmente pensada como significando "carregar", intensificar uma visão negativa de uma pessoa ou situação - em geral por meio do humor -, o uso dessa expressão artística de forma intensa pela publicação se justificava. Contou com desenhistas de grande qualidade e expressão, como por 
exemplo, Alfredo Storn, Benedito Calixto e Raul Pederneiras.

O Malho, intitulado como um "semanário Humorístico, Artístico e Literário", teve como símbolo o martelo (o malho) e em sua primeira capa apresentou um ferreiro com esse instrumento de trabalho e uma bigorna. Ou seja, as informações e as críticas contidas na revista seriam forjadas a marteladas, ou as marteladas estariam disponíveis nos comentários dos articulistas e desenhistas da mesma. Seria a oficina a redação, o martelo a caneta, e a bigorna a mesa de trabalho? Em seu primeiro editorial, entre outras linhas, escreveu:

É de praxe que um jornal que se apresenta desfile perante o leitor boquiaberto um rosário de promessas a que se chama pomposamente - o programa. Iconoclasta de nascença, o Malho começa por atacar e destruir a praxe: não tem programa. $\mathrm{Ou}$, mais exatamente, tem todos, como o seu nome bem o indica: ele é o Malho; tudo que passar a seu alcance será a bigorna. O povo rirá ao ver como se bate o ferro nesta oficina e só com isso ficaremos satisfeitos, com a tranquila consciência de quem cumpre um alto dever social e concorre eficazmente para o melhoramento e progresso da raça humana. [...], Pondo em contribuição todos os elementos necessários ao desenvolvimento do riso, ainda que se riam uns à custa dos outros e nós à custa de todos, temos prestado ao homem em geral e aos que habitam esse canto do planeta, em particular, tão relevante serviço, que não haveria remédio senão criar o governo uma medalha de mérito para nos galardoar, já que esta República, que também não é a que sonhávamos, quando mamávamos, teve a infeliz ideia de abolir o Hábito de Cristo, ficando totalmente desarmada para testemunhar a gratidão da pátria pelos filhos que assim abnegadamente a sabem servir. Em matéria de abnegação, porém, não há ninguém que nos exceda e, já que nos metemos nisso, iremos até o fim; faremos esta salutar reforma de costumes e numa quadra em que todos choram pitangas, estalaremos o riso são, o riso honesto, o riso próprio do homem, sem reclamarmos sequer do Sr. Campos Sales que se sujeita a apanhar mais três dúzias de descomposturas por cumprir o seu elementar dever de condecorar-nos! Cremos que quem assim fila, merece só por isso a mais completa confiança do público [...] Em torno dele só, só há quem lhe fale de coisas tristes[...] Ora, em meio desse coro fúnebre de tristezas e lamentações, soa cantante o bimbalhar do Malho, tirando dessas bigornas sons alegres! É um cartaz de cores vivas no meio de uma decoração de pompa fúnebre; é a nota vibrante de uma cançoneta brejeira a interromper um requiescat de gatos pingados; é o verde da esperança a reflorir os espíritos abatidos e desolados; é o vermelho da blague a dissipar a melancolia geral; é um zé-pereira formidável entrando audacioso e impiamente pela solenidade de uma semana santa; é a audácia, é a alegria, é a sátira, é a crítica, é a mocidade mordaz e irreverente, é a saúde, com a breca! ( $O$ Malho, 20/02/1902).”

Nesse trecho de um longo editorial vemos que a ironia se fez presente desde as primeiras linhas ao se declarar como uma revista iconoclasta. Ao não ter programa, ou ter todos, $O$ Malho se apresenta como uma revista livre, sem ligações com grupos (poderosos), 
visando exclusivamente atender às demandas da sociedade, de seu leitor. Este, ao ver bater o ferro na bigorna, teria a certeza de que ali (na redação) estaria se produzindo algo que lhe agradaria, ou mais, o levaria a ser um cidadão melhor após lê-lo, principalmente por meio da troça. Sua função, portanto, seria servir à Pátria pelo riso, já que este faz parte da sociedade.

Propõe, entretanto, um riso honesto (então há um riso desonesto?), que é próprio do homem. Seria o riso honesto o que produz consciência? Mas é também o que traz alegria, riso descomprometido em meio à crise geral que vivia a população? O Malho seria um Zé Pereira, o personagem carnavalesco tocador de bumbo, que apesar das críticas desde o século XIX, não parava de tocar seu instrumento ensurdecedor anunciando a alegria em meio ao mundo real. Portanto, $O$ Malho trará a audácia da crítica, a irreverência da análise e o riso como fonte da saúde.

Segundo a página da Fundação Casa de Rui Barbosa, tal qual a Careta, a revista $O$ Malho combateu a aliança política que apoiava a candidatura de Getúlio Vargas à presidência do Brasil e não apoiou o golpe de 1930 ("revolução de 30"), sendo sua redação empastelada, sua sede incendiada e a publicação impedida de circular por um breve período (http://omalho.casaruibarbosa.gov.br/).

Para este trabalho foram coletadas cerca de 100 charges envolvendo o carnaval. Destas foram retiradas 21 que compõem o quadro analisado em linhas futuras. A seleção final levou em conta a dimensão e a proposta deste texto. Assim, muitas charges que ajudariam a confirmar as análises apresentadas aqui, bem como aumentar a visibilidade da relação carnaval, política, riso e charge, ficaram de fora.

A escolha do período deste texto se refere, em especial, ao tempo em que Pedro Ernesto Baptista esteve na administração da cidade do Rio de Janeiro (1931-36), primeiramente como interventor (1931-1935) e depois como prefeito eleito (1935-36). Foi em sua gestão que o carnaval passou a figurar na agenda de turismo da cidade e quando as escolas de samba começaram a receber verbas municipais.

Este trabalho comporta duas divisões, a saber: a primeira, uma visão geral do que seria o conceito de charge e uma tentativa de localizar o riso historicamente e sintetizar o riso, o risível, em alguns estudiosos sobre o tema, sem, contudo, procurar esgotar o assunto, pelo contrário, apenas despertando o interesse e ajudando na análise posterior do texto.

A segunda parte busca relacionar o riso, o carnaval, a política brasileira e as charges, ou seja, como os chargistas de Malho e Careta compreenderam esse período histórico construindo 
imagens que provocavam o riso, a crítica e outras reações, tendo como pano de fundo o carnaval e a política. Esta parte é subdividida em duas, o processo de oficialização do carnaval e a política nacional, ambas focando na relação entre o riso, o risível e o carnaval.

\section{A CHARGE, O RISO E O RISÍVEL}

O que é uma charge, o que a compõe, qual seu sentido, a quem se dirige e por quê? Enfim, as perguntas podem ser muitas. Não se pretende responder todas, não há espaço e não se faz necessário para este momento.

Uma charge é um produto artístico impresso, que pode ser isolado, estar dentro de uma publicação impressa e, atualmente, também no formato digital (inclusive com movimentos). Discutindo apenas as que foram e são publicadas em papel, são compostas por desenho ou desenhos (pessoas, animais, prédios, florestas, maquinários, enfim, tudo que possa ajudar a construir a mensagem), cores (dependendo da tecnologia disponível e da publicação), escrita (enunciado, título, narrativas, diálogos entre os personagens, identificação destes etc.) e podem estar alojadas em um retângulo ou quadrado. Os personagens podem ser públicos ou desconhecidos, vir em forma de caricatura ou não. A charge pode estar vinculada a alguma notícia do jornal, inclusive a ilustrando, ou apenas estar ligada à fato notório. Sua localização no jornal e na página podem valorizá-la, a fim de ser mais vista, estar destacada. Notadamente é considerada como formadora de opinião e conter traços de humor, causando o riso. Portanto, o riso pode ser causado pelo conjunto da obra, pelo inesperado ao se concluir a mensagem produzida (pretendida), pela caricatura de um dos personagens etc.

Não se trata de uma realidade, mas de uma perspectiva produzida pelo artista do que está ocorrendo à sua volta. É um tema que possa interessar ao público leitor. A relação artista e proposta política do jornal deve ser levada em consideração, pois o artista é um empregado da empresa jornalística e, como tal, deve atender às demandas do patrão. Pode ocorrer uma junção de interesses entre ambos, seja na imprensa engajada (anarquista ou comunista, por exemplo) ou na imprensa burguesa (ideais liberais, democráticos ou autoritários). Nesse sentido, a aceitação do produto do artista também deve estar em sintonia com o leitor, não apenas no tema, mas na solução proposta, ou seja, o sentido produzido. Se a charge desqualifica um fato, desmoraliza uma instituição ou destrói a moral de uma pessoa, o leitor pode reagir de forma variada frente à mesma. Por exemplo, pode discordar, mas a beleza 
plástica do desenho e a perspicácia do desenhista fazem o leitor admirar a obra, mesmo não concordando com seu conteúdo. Pode gerar um riso ou uma gargalhada se o leitor concordar com a crítica contida, achando os desenhos cômicos e/ou a crítica relevante. Ele pode ter raiva da obra, se o que está sendo apresentado for ofensivo aos seus ideais. Portanto, o riso não necessariamente está presente na charge, nem esta é obrigatoriamente crítica ou formadora de opinião. O riso crítico, denunciador, desqualificado fica por conta da cumplicidade entre o leitor e o artista. Não havendo essa relação comum, dificilmente haverá o riso, pois não há o risível.

O chargista deve conhecer as técnicas disponíveis para melhor tirar proveito e produzir uma charge mais qualificada em termos visuais. Tem que conhecer bem os fatos e os personagens (comportamento social e político), quem são seus leitores de suas obras, a quem ataca e/ou defende. Pode colocar títulos, indicações escritas nos personagens, nomeação destes nos diálogos existentes, fazer relações claras com a notícia vinculada e, principalmente, produzir uma linguagem compatível com seu leitor. Assim procedendo, se há uma proposta de formação de opinião, a necessidade de evitar uma liberdade de pensar do leitor ajuda, isto é, evita que o mesmo possa ler de forma diversa da pretendida. Se deseja uma livre interpretação ou acredita que o leitor vá entender da forma que pretenda, deve fazer com que o quebra-cabeça sugerido pela imagem (desenho, enunciado, diálogos, pano de fundo, personagens etc.), possa de ser visualizado pelo leitor e ter sentido para, assim, conseguir formar opinião sobre a obra (positiva ou negativa).

A literatura pertinente apresenta diversos tipos de caricaturas/charges: de costumes, social, política, de humor, ideológica, entre outras (GAWRYSZEWSKI, 2008 e 2010; CARMONA, 2003; LIMA, 1963). As charges de costumes, de humor e social visam primordialmente o riso, podendo trazer críticas ou não ao que é retratado. Podem reforçar preconceitos ou denunciá-los; seguir consensos ou contestar o status quo; trazer a ironia, o deboche, a ambivalência ou dualidade, componentes ou não da reflexão e/ou do riso. As charges políticas são mais opinativas, ligadas a fatos ou acontecimentos políticos, sociais e econômicos, nacionais ou internacionais (guerras, por exemplo). Em geral têm um alvo específico (individual ou coletivo), o pano de fundo pode estar relacionado com a época do ano, a fato externo ou interno e a linguagem usada pode, igualmente, reforçar a mensagem ou ajudar a compreender o fato retratado. Pode causar o riso, mas pode gerar um estranhamento no leitor por formar sua opinião, dar consciência de um fato ou ato político o qual não havia 
compreendido ou desconhecia, ou possuir leitura diversa da apresentada pela imagem. Portanto, uma caraterística da charge política é desvendar, desnudar uma realidade que estava oculta aos olhos do leitor. Portanto, a charge e a caricatura política possuem um grau de ambiguidade, uma carga emocional que a caricatura comum, a charge comum, a de costumes e de humor, em geral, não contêm.

Por fim, não diferindo muito da charge política, há a charge ideológica, ou seja, uma imagem de personagem político podendo abranger também o fato político envolvido na questão proposta na ilustração, possuindo a agressividade como essência, onde o humor não é o objetivo final, mas pode existir de forma irônica, visando denunciar o caráter do retratado. O uso do grotesco, da zoomorfia, da busca da equivalência com uso de símbolos políticos, é uma de suas possibilidades.

Sintetizando, se a base de algumas charges é o humor, o fazer o riso, a caricatura política e a ideológica estão mais voltadas para embates político-ideológicos, ou seja, defesa de ideais políticos e sociais. Se as demais têm sua vida presa ao seu espaço e tempo, estas duas têm vida mais duradoura, pois extrapolariam limites territoriais e temporais. Com carga agressiva e de crítica forte, denunciam a situação cotidiana do cidadão, desnudando e/ou denunciando o agente, a causa das dificuldades vividas. O humor não necessariamente está presente, podendo ser substituído pelo ódio ou rancor, em vista à denúncia apresentada. Elas podem fazer o riso, mas a formação de opinião faz perder a graça. $\mathrm{O}$ riso se transforma, a reflexão está posta e a compreensão do fato/personagem/situação pode, inclusive, negar a alegria.

Visto que a charge tem o poder de causar o riso, de produzir o risível, de propor uma visão de mundo, de desqualificar uma personalidade pública, uma instituição ou corporação inteira ou mesmo um regime político; visto que a charge pode causar estranhamentos ao leitor pelo seu poder de formação de opinião, de desmistificar e criticar o estabelecido; compreendendo a possibilidade de sua extensão, do grande público que pode abarcar (no caso da imprensa escrita) e do poder de persuasão, nada de se estranhar a preocupação dos agentes estabelecidos, os detentores do poder, em buscar seu controle ou mesmo em usá-la contra seus inimigos.

Embora tenha sido apresentado que nem toda charge procura produzir o riso e não é sua função primordial tal coisa, sem dúvida, na grande maioria das charges, em especial as que contêm caricatura(s) em seu interior, o riso é preponderante. $\mathrm{O}$ artista procura produzir o risível. 
No que se refere à charge, ela pode conter uma ruptura inesperada ao final de sua leitura/compreensão pelo observador. Tal ruptura é uma, ou a, causa do riso. A crítica ou o uso da zoomorfia para, em geral, desqualificar ou desnudar o caráter de um inimigo, o desmascaramento pela inteligência do artista ou o uso de cena grotesca podem provocar riso e até gargalhadas.

O riso é um ato natural do ser humano, mas deve ser analisado como algo historicamente construído, em especial se se pensar no que é risível. Nesse sentido, é interessante perceber como o riso (e o risível) pode ser localizado espacial e temporalmente, pois é uma construção histórica dentro das sociedades humanas. Assim, consideramos o riso uma expressão de sua sociedade, faz parte de um projeto social, de um projeto político. O que é risível hoje pode não ser amanhã. O que é socialmente permitido (aceito) hoje, pode não ter sido ontem. Por sua importância nas relações humanas, o riso foi entendido e interpretado de várias formas.

Para Propp (1992), cada época tem seu sentido de humor e de comicidade, e ele sugere a existência de diversos tipos de riso: riso da zombaria (crítico, com sentido de punição, contendo diversos sentimentos de quem ri, como ódio, satisfação e alegria); riso bom (educativo, realizado com afeto, construtivo); riso maldoso (carregado de ódio de quem ri, fruto de seu fracasso, precisa se sentir superior - é um riso destruidor, provavelmente construído em falsos pressupostos); riso cínico (o prazer está na queda do outro, quem ri carece de piedade); riso alegre (sem punição, ódio ou qualquer outro sentido de quem ri, apenas a alegria pelas coisas alegres, de humor, lúdicas até); riso ritual (quem ri o faz por padrão construído, ou seja, faz parte do rito estabelecido). O riso da zombaria, sem dúvida, por conter os sentimentos mais variados e ser mais facilmente realizado no cotidiano pela maioria das pessoas, é merecedor de mais atenção e o que se encaixaria nas festividades carnavalescas e nas charges de humor. Mas o riso cínico talvez seja o mais comum, hoje, nos meios jornalísticos e o encontrado nas vias públicas. $\mathrm{O}$ riso maldoso, na sociedade atual, deve ser pensado, pois, somado ao riso da zombaria, pode conter o preconceito, comum na sociedade, mas aumentado em épocas de crise (econômica e de limites), como o preconceito racial, social, sexista, nacionalista entre outros (ver também VALE, 2013).

Para Platão, por exemplo, o riso desestabilizava a razão, impedindo o homem de ver o mundo como ele era, ou seja, como este pode governar se não tem a capacidade de compreender a si e ao seu mundo? (FERREIRA, 2013, p. 41).

Para Sócrates, não se devia rir de um amigo, pois seria uma injustiça, traria em seu 
bojo a inveja. Para ele, não é permitido ter prazer à custa de tristeza de um amigo (FERREIRA, 2013, p. 41). Mas nada contra rir do inimigo, pois este é inferior, deve servir ao outro, pode proporcionar prazer, que é a essência do riso. O risível só pode estar naquele que não é próximo.

Uma questão bíblica importante: Jesus riu? Uma questão teológica que tem gerado debates, pois coloca o riso como peça central. É lícito rir? Quando? De quem? Minois (2003) afirma que no Paraíso não haveria razão para rir, pois o mundo era perfeito e harmonioso. Foi com o Pecado Original que o mundo se desequilibrou e o riso surgiu. Aqui podemos discordar de Minois, pois o riso não é necessariamente um desvio, pois ao ver algo belo (Eva, por exemplo) Adão poderia sorrir, um riso de alegria, comunicativo, que causaria um sorriso do sentido contrário. De um sorriso, Eva e Adão poderiam partir para um riso. A vida bucólica do Paraíso, com as sensações das descobertas, certamente causaria o riso nos dois habitantes. Esse mesmo autor apontou para a existência, na sociedade, de vários risos (como Propp), podendo ser agressivos, sarcásticos, amigáveis, entre outros. Podem se originar de formas diversas, como a irônica, burlesca ou grotesca, na maneira ambígua, multiforme ou ambivalente. Seriam todos apenas depois da expulsão do Paraíso?

Para Baudelaire (1998), o riso humano estaria intimamente ligado à degradação física e moral de alguém, à feiura física de moral do homem. Tanto o riso como a lágrima são filhos da aflição, portanto, trazem também a possibilidade de redenção. No Paraíso não haveria dor, portanto, a ausência do riso e da lágrima. Esse autor também difere a alegria do riso, pois o primeiro existe por si mesmo, o segundo é um sintoma. A primeira é, o segundo contraditório. $\mathrm{O}$ primeiro seria como o sorriso de uma criança, inocente, o segundo o riso de um homem (verdadeiro, violento) causado pelo grotesco. Baudelaire destaca em sua obra que o riso vem da superioridade do homem sobre o homem. Por fim, um aspecto que chama atenção, ligado a essa questão, é que o risível não estaria na coisa, mas no leitor, é neste que se encontra o cômico, pois é sua forma de pensar o outro que torna a coisa risível.

A Igreja Católica, detentora do poder político e ideológico na Idade Média, buscou construir uma ideia de o riso ser aliado do diabo, uma vez que aquele poderia ser visto como um importante ingrediente na desconstrução da ordem estabelecida se não fosse contido, controlado (FERREIRA, 2013, p. 43).

Segundo Vale (2013, p. 90), no Renascimento o riso ofereceu ao homem se mostrar civilizado, inteligente e espirituoso. Podia-se tornar estimado pelas pessoas, conquistando 
novos amigos e, por fim, obter técnicas para se esquivar do ridículo e do riso alheio. Para Bakhtin, é nesse período que o riso passou a ter uma significação positiva, criadora e regeneradora.

Para Freud (1996), seguindo sua linha de raciocínio, o riso estaria vinculado ao alívio, necessário diante das repressões que a psique sofre (gera). O riso surge, então, como um muro protetor à dor, ao desconforto, à opressão (que não deixa de existir com o riso). Nesse sentido, essa teoria muito bem se aplica ao carnaval, uma festa de transgressão, cantorias e descontração, pois é por meio dessas ações que o homem alcança o riso, uma alegria inexistente nos outros dias do ano. Relembrando que o carnaval possibilita essas ações por diversas formas/sentidos (escrita, verbal, visual, auditiva etc.), o riso pode ser solto: pode-se gargalhar, "morrer de rir", não há limites. Aparentemente, pode-se rir de tudo e de todos, até de si mesmo.

Considerando o carnaval como uma festa popular às avessas, quem está em cima fica por baixo e quem está em baixo fica por cima, o homem se transveste de mulher e a mulher de homem, é a festa das contravenções, liberdades, liberalidades, críticas, xingamentos e outras formas de burlas. Isso em sentido amplo, pois envolve o visual/imagem (cores, texturas, vestimentas/fantasias, carros alegóricos etc.), a linguagem (musical, verbal, escrita e corporal) e o espaço ocupado pela festa (público, privado, oficial, eclesiástico etc.). Há a construção de cenas grotescas, lúgubres, coloridas, coletivas, individuais, políticas, lúdicas etc., representação de desejos reprimidos, contra políticos, governantes, ódios, sexismo etc.

Neste sentido, voltando ao escritor Bakhtin (1993), este fornece importantes informações sobre o carnaval na Idade Média, onde o riso era permitido, a transgressão era uma norma, mas tudo devidamente dentro de limites controláveis. Apresenta um riso, o riso festivo, que seria coletivo, pertencente ao povo e nascido com ele. Mas, talvez e principalmente, é um riso da burla, sem ser destruidor do status quo; iguala os homens, mas não em um mundo irreal, e a estabilidade do mundo é restabelecida com o fim do carnaval. $\mathrm{O}$ medo é substituído pela alegria e o riso. Pode-se rir de tudo e de todos, um riso livre, quase espontâneo (ou se ri agora ou nunca mais). Seu limite é temporal, preciso, limitado. Mas, em uma sociedade uniforme, sem conflitos, harmoniosa, haverá o riso carnavalesco? Existe esse riso carnavalesco hoje? Talvez Bakhtin tenha deixado uma luz na questão, ao colocar o carnaval em seu espaço físico e temporal: “O carnaval propriamente dito [...] é uma forma sincrética de espetáculo de caráter ritual, muito complexa, variada, que sob base carnavalesca 
geral, apresenta diversas matizes e variações dependendo da diferença de épocas, povos e festejos particulares" (1997, p. 122).

A produção do riso por meio da imagem, do texto, das vestimentas, das letras das canções, das cores, enfim, uma infinidade de realidades que se cruzam ou não e formam o cômico, o humor, o risível, analisadas neste texto, estão associadas ao período carnavalesco carioca (dezembro-março). O riso causado, sóbrio ou escancarado, vai depender de quem ri e do que ri. As imagens com tema carnavalesco poderão ou não agregar os itens considerados, mas vai depender do tema tratado e da(s) pessoa(s) envolvida (s) nas imagens.

Diferente da comicidade falada ou da escrita, em que o ouvinte ou leitor constrói em sua mente a imagem do discurso de humor para depois ser produzido o riso, na charge e nas fantasias do carnaval a imagem já está dada, geralmente pouco necessitando de interpretação. Portanto, no caso do canto, dá-se o primeiro, ao ouvir a música, que pode conter diversas formas de acionar o riso (descrição de um fato cômico, em geral produzindo rima), o ouvinte visualiza o fato e depois cai no riso, que aumenta para gargalhada ao participar cantando. No caso da charge, como foi dito, o quebra-cabeça deve ser montado, o que pode envolver escrita e imagem. No caso de algumas charges analisadas neste texto, farão uso da letra de música para enriquecer a mensagem, cômica ou não, mas sempre crítica.

\section{CARNAVAL, CHARge, RISO E POLÍtica}

\section{OFICIALIZAÇÃO DO CARNAVAL E AS CHARGES}

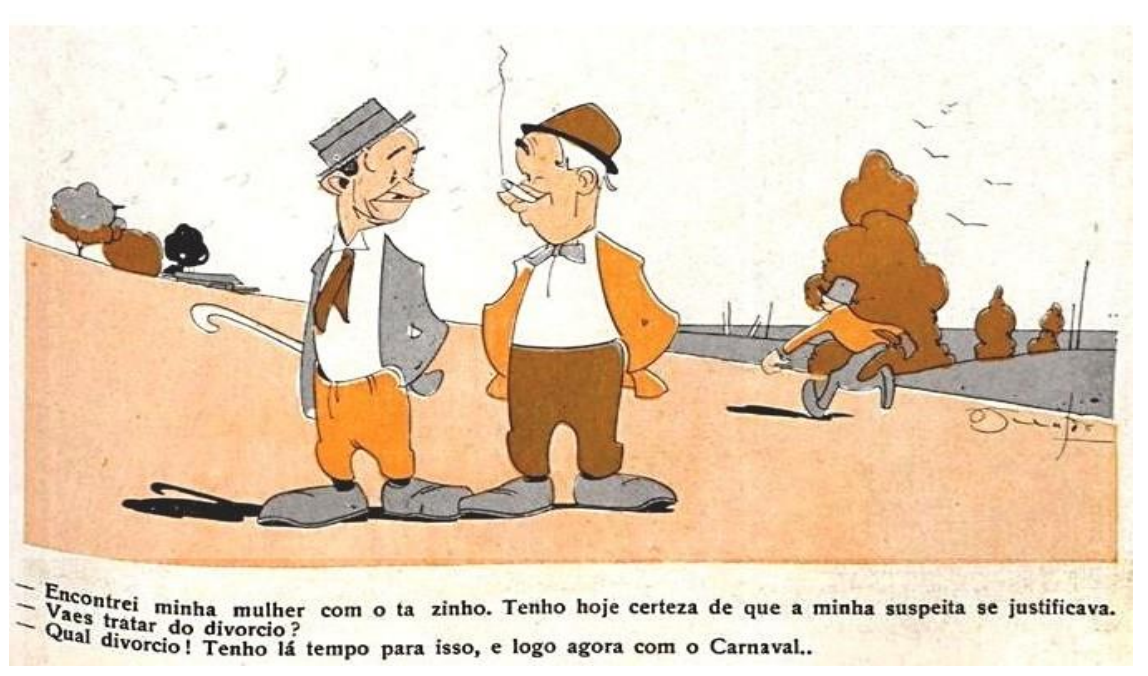

Charge 01

Fronteiras: Revista de História | Dourados, MS | v. 20 | n. 35 | p. 14 - 45 | Jan. / Jun. 2018 


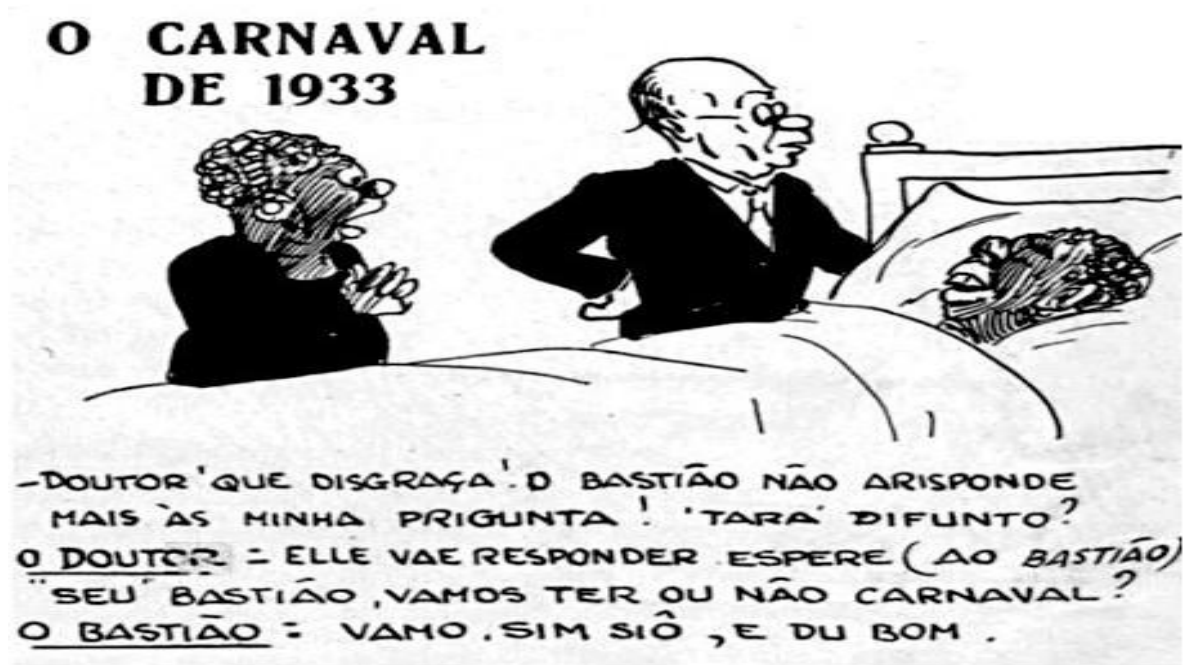

Charge 02

A charge 01, de fevereiro de 1931, publicada na revista Careta, busca o riso fácil. Com traços simples, dois cidadãos conversam sobre a traição feminina. "Encontrei minha mulher com o talzinho. Tenho hoje certeza que a minha suspeita se justificava", diz um dos homens. A outra pergunta: "Vais tratar do divórcio?" Seu parceiro de conversa responde: "Qual divórcio! Tenho lá tempo para isso, e logo agora com o Carnaval..." A charge 02, intitulada “O carnaval de 1933”, publicada na revista O Malho, também é significativa para entender a importância do carnaval que os desenhistas quiseram mostrar para o povo. Médico branco atende família negra, que fala um português errado. “-Tará difunto?”, pergunta a senhora. O médico, então, questiona ao "seu” Bastião: "Vamos ter carnaval?” O Bastião responde: "Vamo sim siô, e du bom”. Em síntese, carnaval levanta defunto, adia divórcio. A alegria corre nas veias do povo e sua alegria maior está no carnaval, seja na doença, seja na traição.

Essa forte relação do povo com o carnaval nunca passou despercebida pelos que detinham o poder. A remodelação da cidade do Rio de Janeiro, no início do século XX, se não marcou o início da busca pelo controle da festa, pelo menos deu um impulso. Hábitos cotidianos, como vender animais nas ruas do centro remodelado, foram reprimidos, festas e procissões religiosas e pagãs igualmente. A inclusão de novos hábitos e vestimentas festivas foi estimulada, a europeização do carnaval foi bem-vinda. Pierrôs e Colombinas substituíram a fantasia popular do diabo e de dominó (CUNHA, 2008, p. 169). Automóveis, com a elite branca fantasiada, formando uma unidade por meio de serpentinas (os corsos), foram o sucesso do carnaval de então. Os ranchos e as associações (clubes) carnavalescas, que tinham como seus sócios elementos de diversas categorias sociais, passaram a dominar o carnaval com seus Fronteiras: Revista de História | Dourados, MS | v. 20 | n. 35 | p. 14 - 45 | Jan. / Jun. 2018 
desfiles na avenida recém-aberta (Av. Rio Branco), onde seus carros alegóricos chamavam a atenção pelas suas dimensões, cores e elementos decorativos.

O carnaval como festa popular não parava de crescer, em todas as partes da cidade blocos carnavalescos saíam às ruas para comemorar a data. O germe das escolas de samba estava surgindo, atingindo seu ápice no início da década de 30.

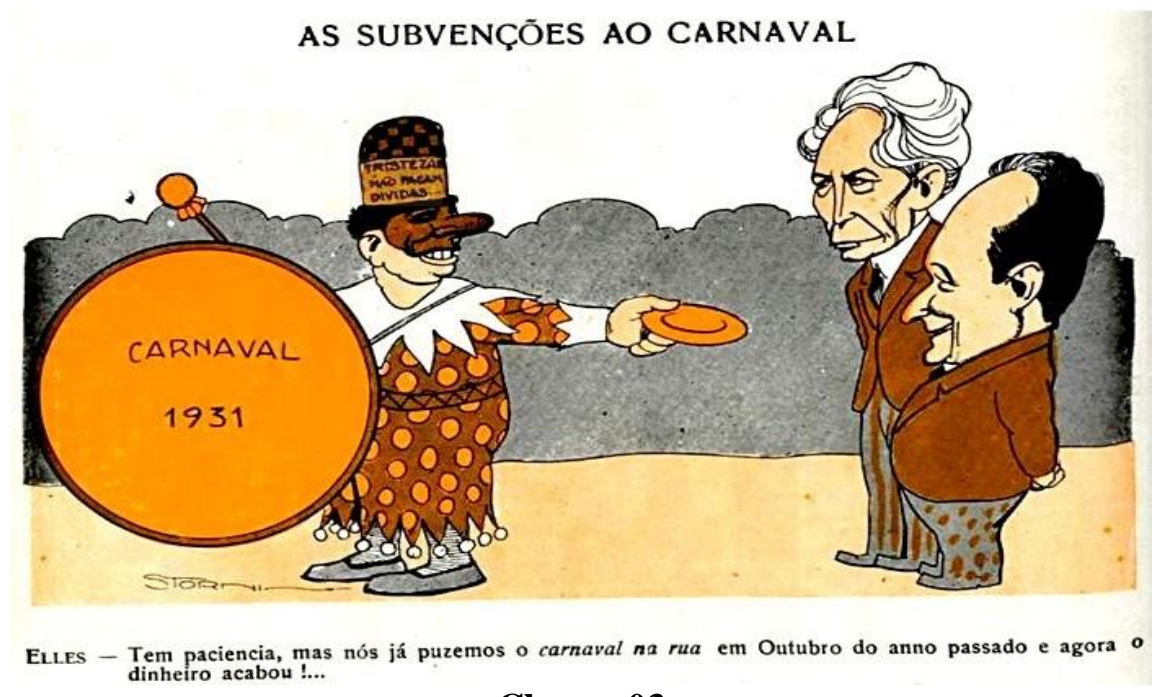

Charge 03

(AS SOCIEDAdes CARNAVALESCAS RESOlVERAM REUNIR-SE EM UMA FRENTE UNICA).

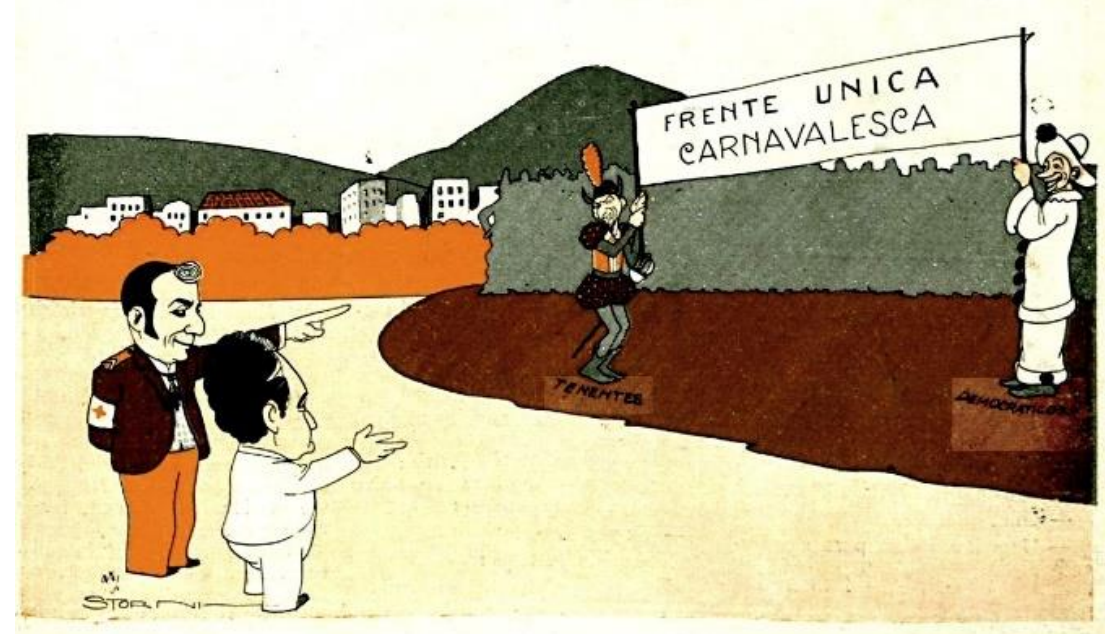

Pedro ERnesto - Está vendo V. Exa. ? Passou o perigo. Estão todos adherindo aos Tenentes...

Charge 04

Fronteiras: Revista de História | Dourados, MS | v. 20 | n. 35 | p. 14 - 45 | Jan. / Jun. 2018 


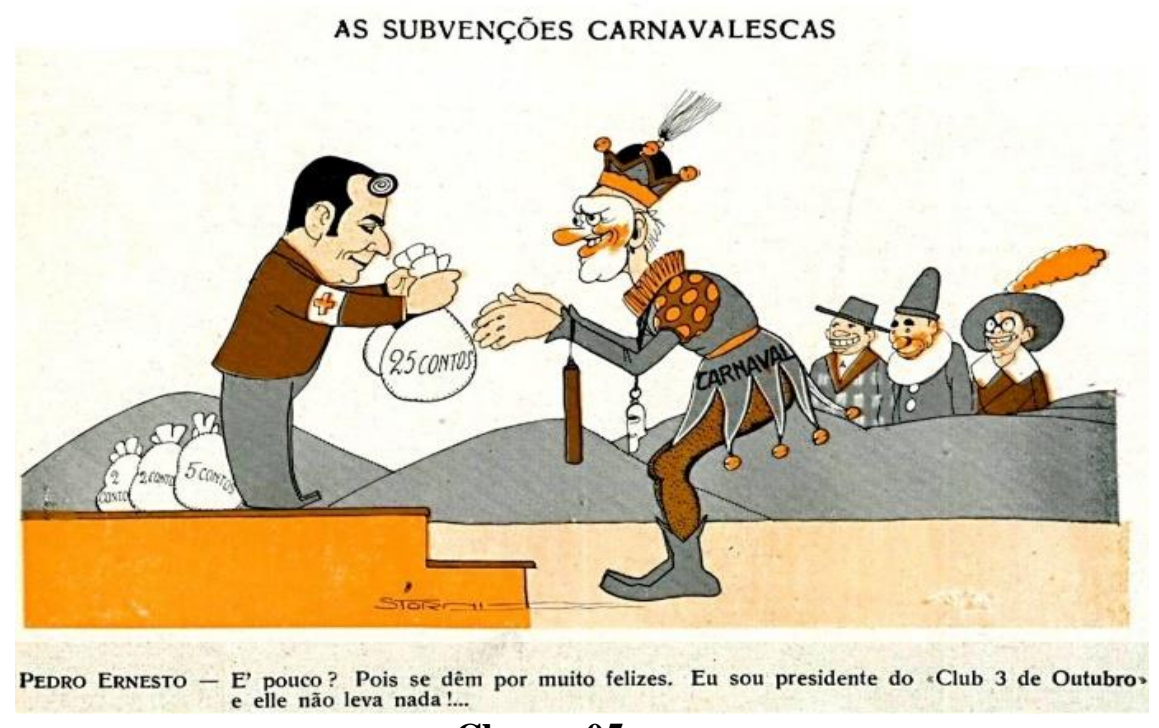

Charge 05

Três Charges de Storn, publicadas na revista Careta, trazem cronologicamente a visão do artista sobre o apoio financeiro da prefeitura da cidade do Rio de Janeiro (Distrito Federal) nos anos de 1931 e 1932. A charge 03 apresenta o personagem clássico do Zé Pereira, com seu bumbo (onde está escrito “carnaval de 1931”), devidamente fantasiado e com um chapéu estilo coco (onde se lê a frase: "tristezas não pagam dívidas", - ver discussão sobre essa música mais adiante). Zé Pereira estende o prato solicitando ajuda ao governo federal para o carnaval. $\mathrm{O}$ presidente Vargas responde que não poderia ajudar por ter gasto todo o dinheiro com o “carnaval de rua de outubro do ano passado". Para o carnaval festivo não havia dinheiro, mas houve para o carnaval revolucionário de 1930 ("revolução de 03 de outubro de 30", que depôs o presidente eleito Washington Luiz, 1926-30). Como vimos, a revista não apoiou o chamado movimento "revolucionário" e, seguindo essa linha, o artista compara esse movimento a um carnaval.

Na charge 04, 10 meses depois da primeira, Storn volta à carga, agora anunciando uma trégua política no carnaval, onde as sociedades carnavalescas "Tenentes do Diabo" (de roupa escura) e "Democráticos" (de roupa clara) teriam formado uma frente única para defender o carnaval (título da charge). O prefeito-nomeado Pedro Ernesto, que era médico, diz ao seu chefe Vargas que todos estavam aderindo ao Tenentismo (corrente importante que apoiou a "revolução de 03 de outubro de 30" e que se organizava em torno do Clube 3 de Outubro e do qual Pedro Ernesto era presidente). Novamente, objetivando o riso e a crítica, o chargista relaciona um fato do carnaval com a política nacional. 
Por fim, a charge 05, de 30 de janeiro de 1932, com o título "Subvenções carnavalescas", mostra o prefeito Pedro Ernesto oferecendo um saco de 25 contos para um mascarado fantasiado, simbolizando as grandes sociedades. Para este, Pedro Ernesto diz: "É pouco? Pois se deem por muito felizes. Eu sou presidente do "Club 3 de Outubro" e ele não leva nada!...”. Novamente o chargista menospreza os “tenentes" que possuem uma associação, deixando transparecer ser um clube carnavalesco, local de festas e bailes, e não uma agremiação política séria.

Pedro Ernesto foi um pernambucano que veio concluir seu curso de medicina no Rio de Janeiro, e se sustentava fazendo desenhos e tocando instrumentos musicais. Quando jovem, atuou na vacinação nos morros cariocas, o que lhe possibilitou fazer muitas amizades e ser convidado como padrinho de muitas crianças. Então era um sujeito que conhecia bem as necessidades financeiras e de assistência social e educacional da população carioca, assim como sua cultura popular. Quando de sua morte (1942), diversos recibos de pagamento de remédios e gastos com sepultamentos foram encontrados em sua gaveta na Casa de Saúde Pedro Ernesto, uma das mais importantes da cidade (GAWRYSZEWSKI, 1988). Ou seja, foi um benfeitor para seus pacientes e amigos pobres.

Pedro Ernesto foi um expoente, desde 1922, no movimento tenentista, que atuou diretamente na "revolução de 30". Ao assumir a prefeitura da cidade do Rio de Janeiro (Distrito Federal), buscou fazer uma administração voltada para a educação e saúde, e via no turismo uma importante fonte de renda para gerar impostos. Além dos cassinos, que foram abertos na cidade, Pedro Ernesto viu no carnaval outro forte instrumento de atração turística. Assim, em 1932, o carnaval, com o desfile das sociedades carnavalescas, passou a estar inscrito no programa oficial das festas da cidade. Por meio dessa oficialização, as Sociedades Carnavalescas obtiveram apoio financeiro para o melhoramento de seus desfiles (como visto na charge 05). Essa iniciativa teve grande repercussão e apoio na imprensa carioca (GAWRYSZEWSKI, 1988). A charge 06 apresenta Pedro Ernesto, devidamente fantasiado, sobre os ombros do rei Momo, com uma flâmula na mão direita onde está escrito "Viva a imprensa". Ao fundo, o apoio de um folião. O rei Momo se dirige para o "Novo Congresso". Nesse momento, o congresso estava fechado (desde a "revolução de outubro de 1930"). Intitulada de "Carro de Crítica" (era um típico carro alegórico do carnaval carioca), pode sugerir o despontar de um novo político popular, com assento garantido em um novo congresso (mas, qual cadeira?). Mas, também, pelo título, pode indicar que o novo congresso seria 
composto por foliões políticos ou políticos foliões, tornando cômica a visão da nova política nacional.

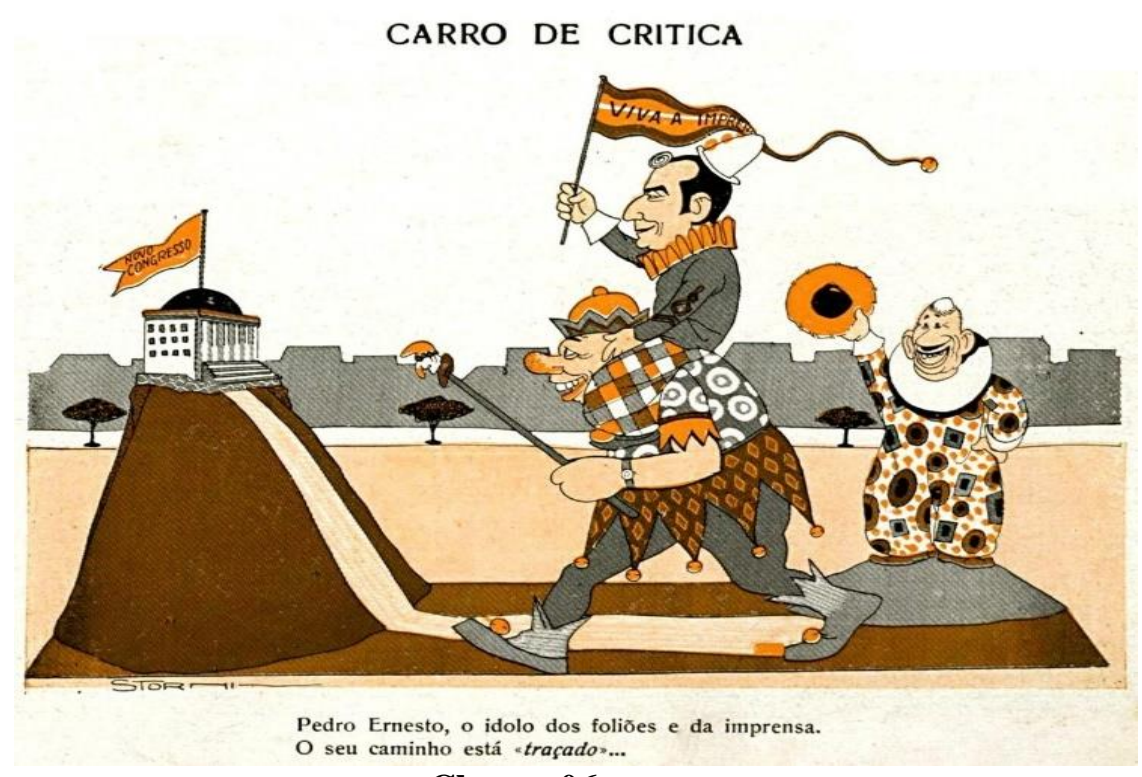

Charge 06

Diversos autores apresentam essa oficialização do carnaval e, posteriormente, a inclusão das escolas de samba como receptoras de verbas públicas, como mais uma forma de manipulação política, ou seja, incorporar para controlar (ALMEIDA, 2013; CONNIFF, 2006). Colocar o papel de Pedro Ernesto nessa perspectiva não contribui para compreender essa nova relação do estado com a sociedade e sindicatos no pós-30. Pelo contrário, ao se colocarem todos os políticos e suas ações em um mesmo conjunto, ignoram-se as diversas correntes (projetos políticos) que estavam em jogo no período. Se na charge 03, por exemplo, Vargas não apoia o carnaval, e se nas charges 04 e 05, Pedro Ernesto vê com bons olhos um diálogo com os setores populares, o que se conclui (fora os aspectos críticos e cômicos das imagens) é que havia diferenças de visões dos que estavam no poder. Por fim, a charge 06 aponta Pedro Ernesto como um novo líder popular (ou carnavalesco?). A oficialização do carnaval foi motivo de diversas charges das revistas aqui estudadas, às vezes de difícil compreensão, pois exigem uma leitura com conhecimentos de fatos específicos da época. Abaixo, duas imagens como exemplos. 


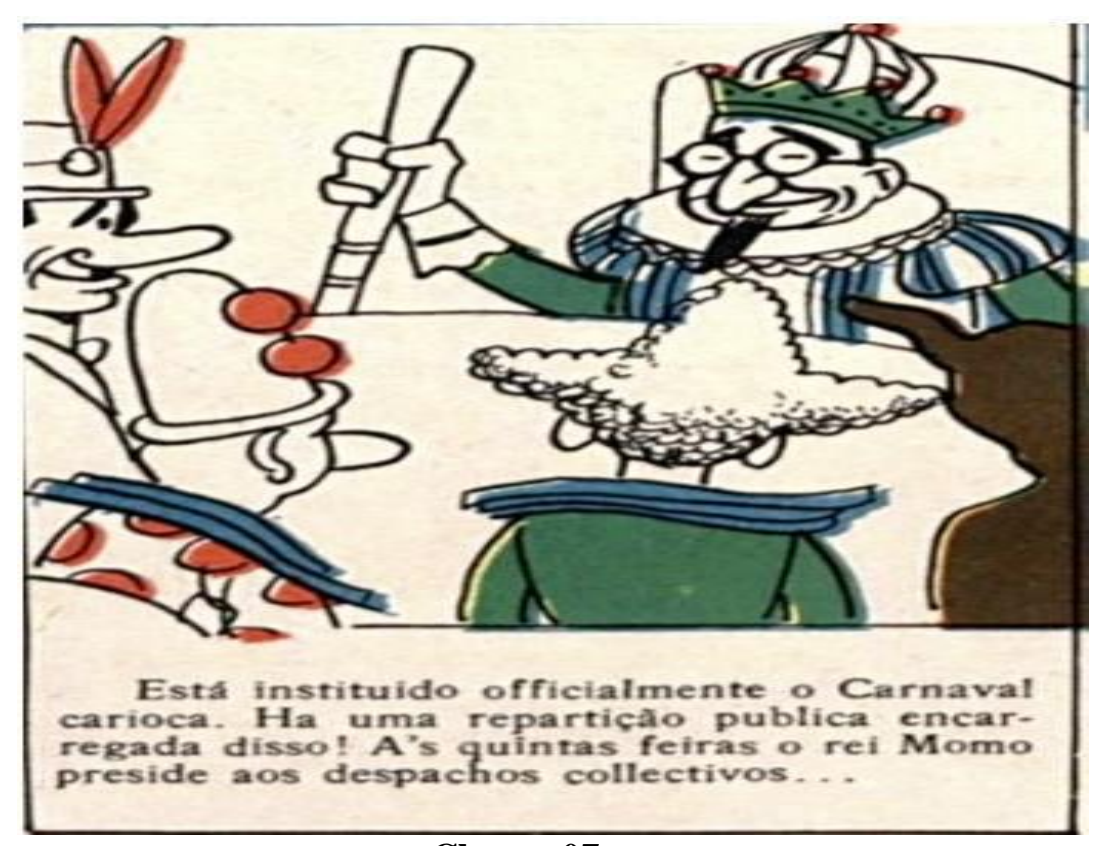

\section{Charge 07}

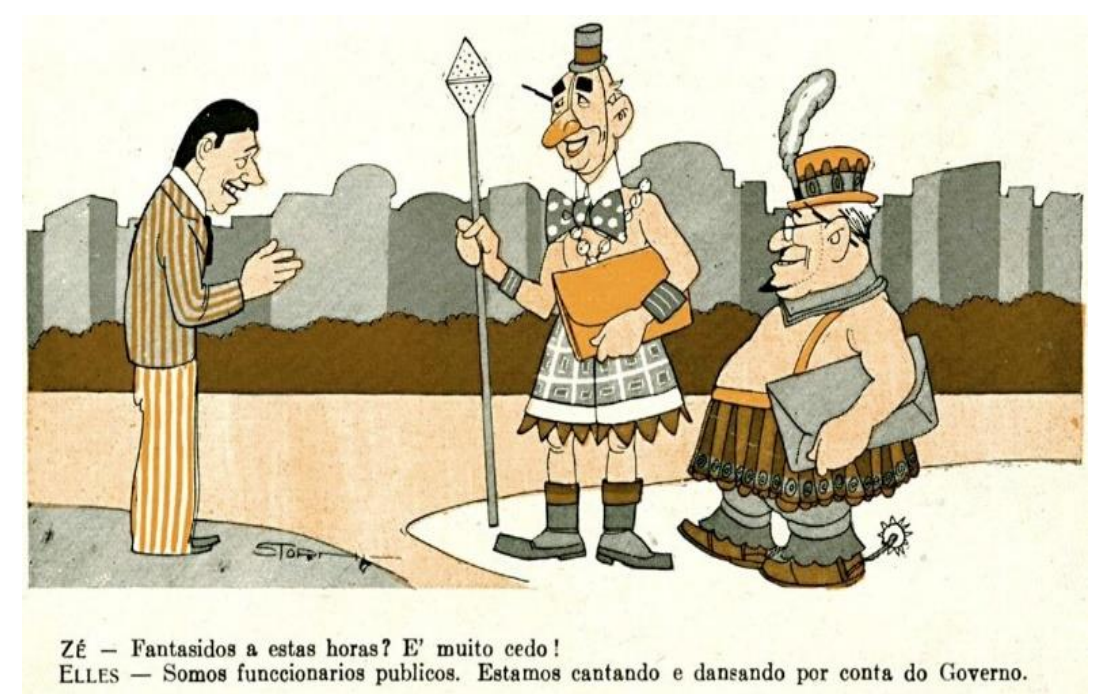

Charge 08

Na charge 07 um rei Momo (com traços semelhantes aos de Vargas) despacha com seus subordinados, também devidamente trajados, sobre a oficialização do carnaval de 1934 (charge é de 21/12/1933). Às quintas-feiras o rei Momo presidiria os despachos coletivos, pois passou a haver uma repartição pública para administrar o carnaval oficial. Ou seja, mais um cabide de empregos públicos. Seria composto pelo Pierrô, a Colombina, o Zé Pereira? Seria o gabinete do rei Momo decorado com serpentinas e sobre a mesa haveria sacos de confete? $\mathrm{O}$ 
que o leitor teria imaginado ao ver tal imagem? Riso pelo deboche? Raiva pelos impostos pagos? Os dois?

A charge 08 vai no mesmo sentido. Datada de 18/02/1933, portanto, dois meses depois da anterior, próximo das festividades carnavalescas, traz dois funcionários públicos vestidos a caráter, ou seja, prontos para brincar o carnaval. "Somos funcionários públicos. Estamos cantando e dançando por conta do governo". Se os jornais diários (O Globo, Jornal do Brasil, A Nação, entre outros) apoiavam a concessão financeira às entidades carnavalescas, os chargistas de $O$ Malho e Careta aproveitaram a oportunidade para apresentar seu lado da questão, não propriamente contra a concessão, mas com críticas ao modelo administrativo existente nos serviços públicos.

Passados alguns anos, duas charges mostram mudanças significativas na organização da festa carnavalesca. Em abril de 1935 foi instituída a Lei de Segurança Nacional (LSN), após longo tempo de tramitação no Congresso Nacional. Em 1936 foi ainda mais radicalizada, com a criação do Tribunal de Segurança Nacional, criado para julgar os crimes previstos naquela lei. E, em novembro de 1937, foi implantada a ditadura do "Estado Novo" (1937-45), que fechou o Congresso Nacional, e cassou deputados, senadores, prefeitos e governadores. A liberdade de imprensa estava suspensa e as garantias pessoais e constitucionais do cidadão idem. Na charge 09, o presidente Vargas contratou o rei Momo para o carnaval de 1935, mas o advertiu para que não houvesse excessos liberais em função da LSN. Nota-se que a charge é anterior à aprovação da referia lei. A sutileza de "elefante" de Storn chama a atenção para seu compromisso de denunciar uma situação que adviria em breve: controle das liberdades individuais e coletivas. Vargas é apresentado como um homem desligado do pensamento liberal e democrático. Contrata Momo, mas o tenta controlar. Destaca-se a desproporção entre os dois corpos. 


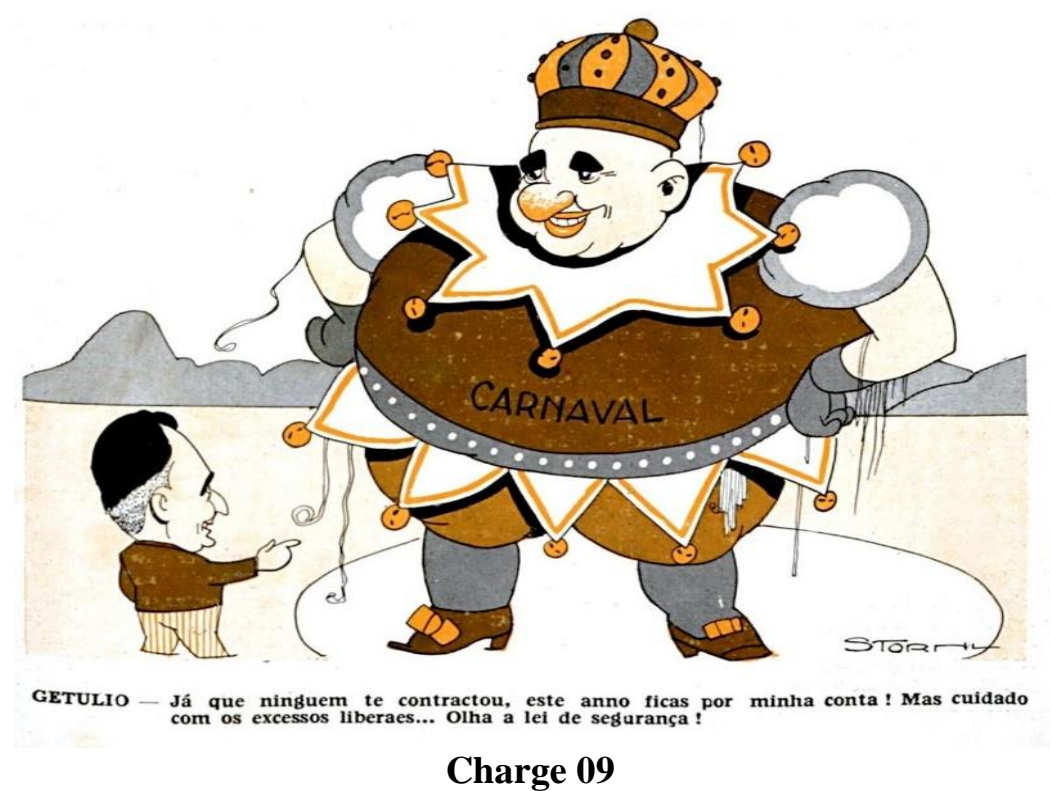

A charge 10 é de autoria de J. Carlos, chargista que se posicionou francamente contra o "Estado Novo" e em defesa das liberdades democráticas. Aproveita uma brecha na censura e consegue publicar, em capa, uma imagem aparentemente lúdica, mas com forte conteúdo político. O carnaval, como no caso da charge anterior, é usado como pano de fundo para denunciar a ditatura recém instituída. Intitulada “As meninas do barulho são de paz", mostra que, ao chegar em casa, o pai, um senhor com traços simplórios, se espanta com a cena que se apresenta e pergunta: "Uê! Que negócio é esse? A família toda reunida!” A senhora responde: “As meninas querem saber se há alguma lei nova contra o Carnaval". A que lei elas se referem? Por que haveria lei contra o carnaval? Contra o carnaval ou por temas das letras dos sambas, das charges sobre o carnaval, ou charges relacionando carnaval com o governo ou por carros alegóricos contestadores do regime ou, pelo contrário, com exigências? Exigências de sambas exaltadores do regime, da vida pelo trabalho, da vida feliz nos morros? Enfim, J. Carlos deixou em aberto muitas possibilidades que, na realidade, já estavam em andamento pelo regime estadonovista. O riso é demolidor, denunciador. Os que viam com críticas a situação nacional no pós-37 não poderiam deixar de sorrir pela satisfação pela imagem proposta, pela denúncia contida. 


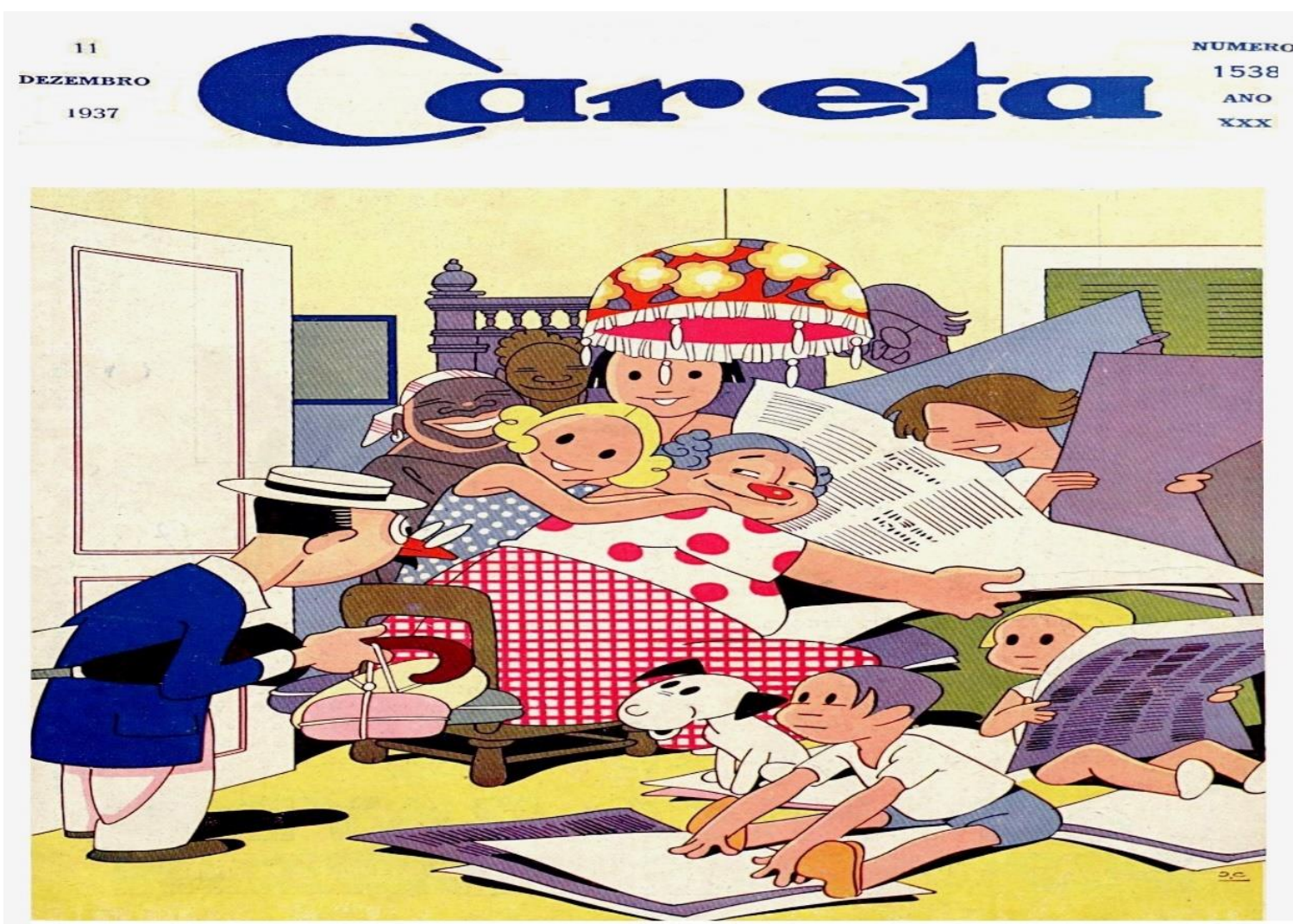

Capital 500 réis

As meninas do barulho são de paz

Estados 600 réls Uê ! Que negocio é esse? A familia toda reunida?!

\section{Charge 10}

\section{CARNAVAL, MÚSICA E CHARGE}

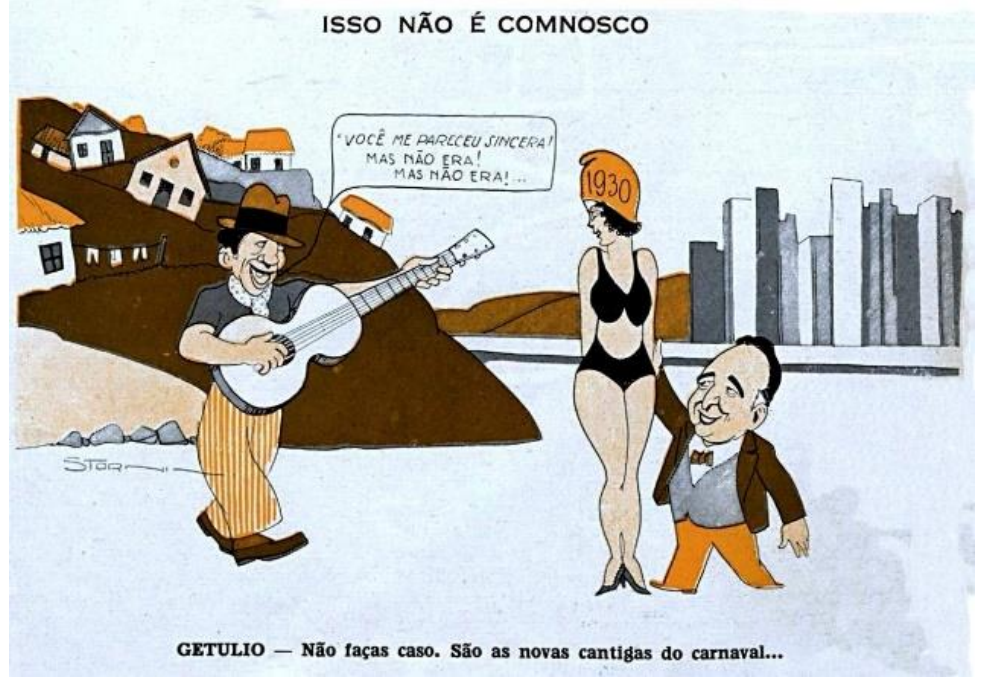

Charge 11

Fronteiras: Revista de História | Dourados, MS | v. 20 | n. 35 | p. 14 - 45 | Jan. / Jun. 2018 


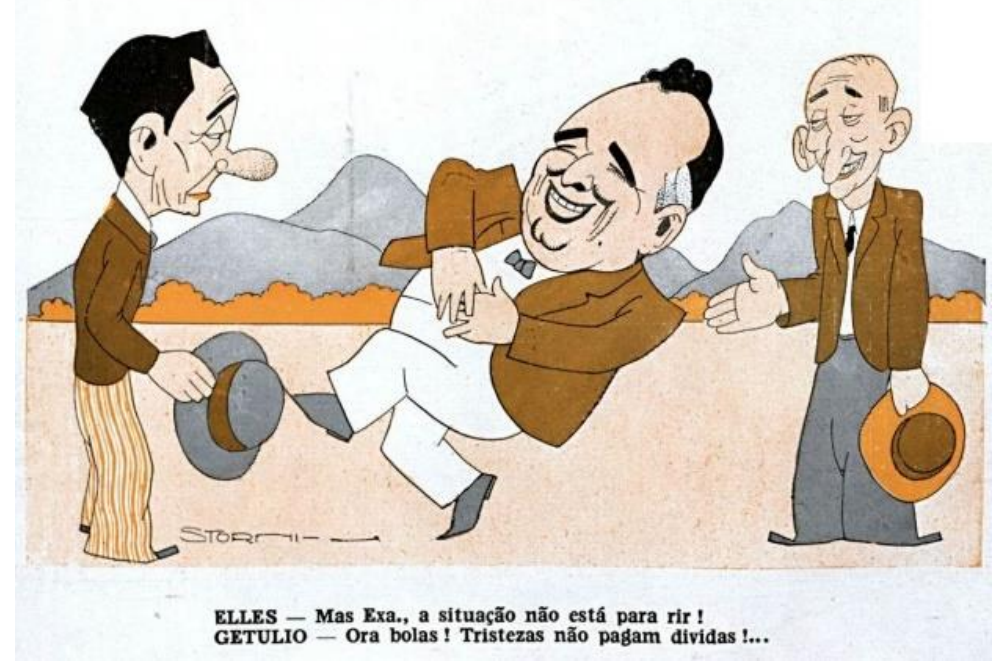

Charge 12

A charge 11 (05/01/1935) é rica em detalhes - com título, legenda, letra de música, representação da república (de 30), malandro com sua vestimenta e os espaços urbanos definidos - e nos traz novamente a figura de Getúlio Vargas. O título "Isso não é conosco" é uma referência de que as palavras não tinham nada a ver com os personagens, que poderia ser até mais uma frase de Vargas, semelhante ao que disse à república: "Não faças caso. São as novas cantigas do carnaval...". Ao ouvir a música ("Você me pareceu sincera! Mas não era!...”), a personagem feminina (com o barrete frígio na cabeça, signo da república francesa, devidamente adaptada ao Brasil pela data e pelos trajes de praia) voltou-se para o cantador e prestou atenção ao mesmo. O sambista, tipicamente trajado (não com a camisa listrada, mas a calça), com lenço no pescoço, como que saindo da favela - o morro, onde nasceu o samba, devidamente retratado, com as roupas ao vento, em contraposição à cidade, caracterizada pelos prédios, toca seu violão. Pode-se traçar uma linha diagonal na imagem, onde se vê, claramente, a divisão existente entre a cidade dos prédios (da "república"?) e a cidade dos barracos (do "povo"?).

A letra da música, intitulada "Joia Falsa", escrita por Osvaldo Santiago, foi gravada para o carnaval de 1935 pela voz de Gastão Formenti. Vê-se, mais uma vez, a música e a carnavalização da política, ao se colocar na voz do povo mais humilde a ilusão do que estava sendo a república pós-30. Uma desilusão, pois a mesma não era sincera, apenas aparentava. Ao desprezar o cantor, Vargas ignora o povo e se apega ao poder. O chargista Storn busca o riso crítico, sua obra visa denunciar os descasos do governo, desmascarar a figura do Fronteiras: Revista de História | Dourados, MS | v. 20 | n. 35 | p. 14 - 45 | Jan. / Jun. 2018 
presidente Vargas.

Três meses depois, logo após o carnaval, Storn volta à carga contra Vargas, conforme se vê na charge 12 (16/03/1935). Desta vez sem título e sem grandes detalhes, dois personagens com traços de serem desprovidos de recursos financeiros, comentam com Vargas que a situação não estava para risos. Este, gargalhando, responde: “Ora bolas! Tristezas não pagam dívidas!...”. Vargas de riso passou para a gargalhada, com a boca bem aberta, dentes à mostra e mãos na barriga, deixando claro sua alegria com a resposta imediata. O leitor não ri do presidente, este sim ri do leitor. A palavra "tristeza" se contrapõe à alegria do chargeado. A ambivalência está posta em detrimento do leitor. A charge não é geradora de riso, mas de inconformismo, de raiva. Uma música carnavalesca, que o povo cantava nas ruas e que não tinha relação com a questão econômica, mas com a dívida feminina para com o seu homem amado.

Para o carnaval de 1932, uma letra teve destaque nas charges das revistas $O$ Malho e Careta: "Gosto, não é muito", de autoria dos famosos compositores Noel Rosa e Ismael Silva, sendo gravado pelo mais importante cantor de então, Francisco Alves, o "Rei da Voz".

Olha, escuta, meu bem/ É com você que eu estou falando, neném/ Esse negócio de amor não convém/ Gosto de você, mas não é muito...muito! /Fica firme, não estrilha /Traz o retrato e a estampilha/ Que eu vou ver/ O que posso fazer por você.

Seu amor é insensato/ Me amofinou, mesmo, de fato/ Não leve a mal/ Eu prefiro a Lei Marcial. 


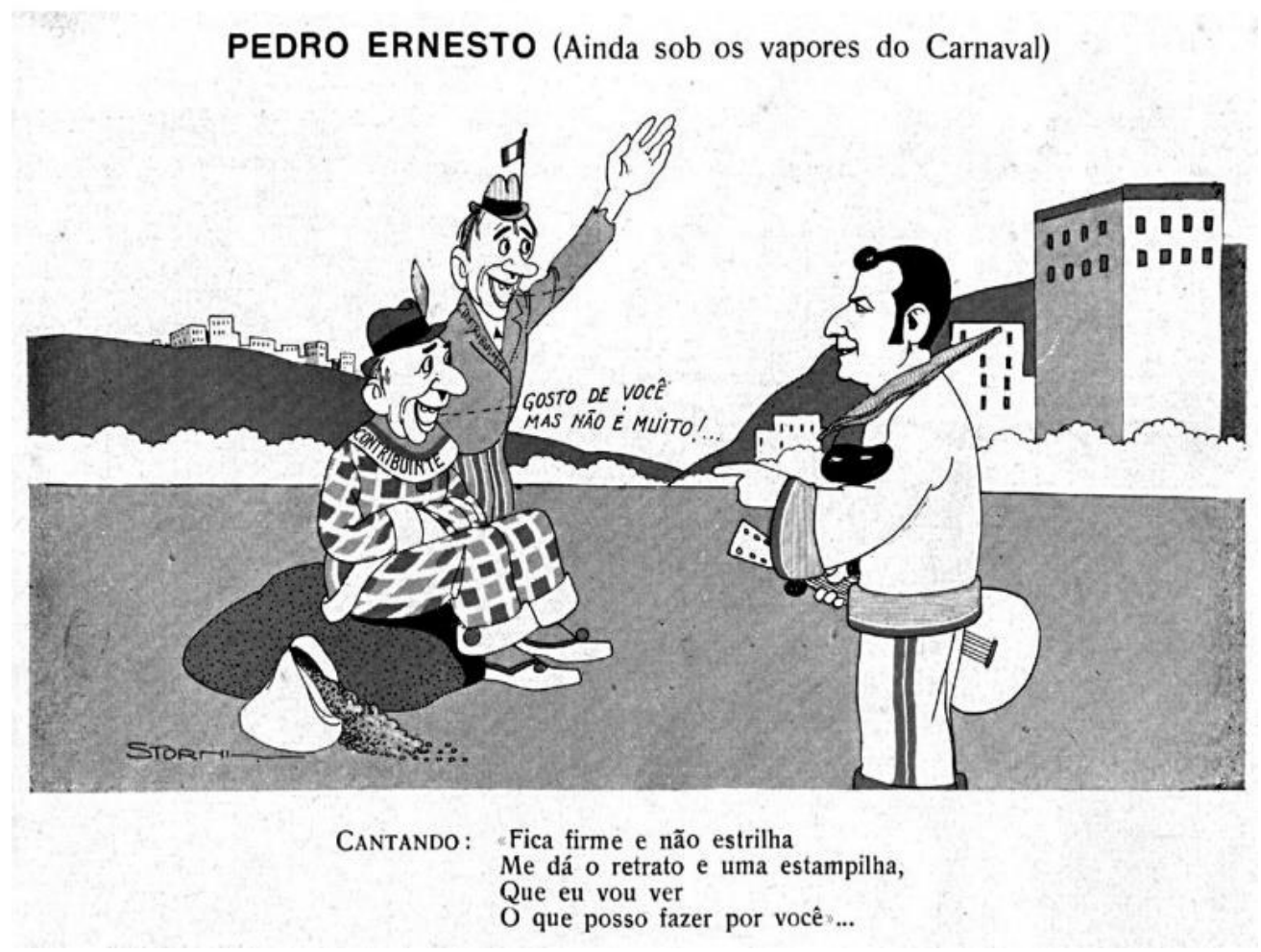

\section{Charge 13}

Na charge 13, intitulada "Pedro Ernesto (Ainda sob os vapores do Carnaval)", há a figura do prefeito da cidade, Pedro Ernesto, devidamente vestido para o carnaval e na mão direita um instrumento típico dessa festa, o violão. Duas outras figuras compõem a imagem, um com sua roupa de carnaval, o outro de traje comum, ambos identificados como contribuintes da municipalidade. Ao chão, um saco de confete. Da boca de um contribuinte sai um estribilho da música "Gosto de você, mas não é muito!...”. O outro está de boca aberta, mas, aparentemente, nada diz. Pedro Ernesto aponta para o contribuinte que canta, está sorrindo. A charada é quem está cantando a parte da legenda, se Pedro Ernesto ou o contribuinte cantador. Como a letra solicita um retrato em uma estampilha, que é o selo do imposto, o cantador deve ser o prefeito. Entendido assim para o leitor, quis o autor da charge apresentar, por meio do riso, uma situação de 1932. O prefeito goza de prestígio junto ao povo, mas não é muito! Pedro Ernesto simplesmente cobra mais um imposto para tentar fazer alguma coisa pelo contribuinte. A dualidade que causa o riso é justamente a reclamação dos impostos ter gerado mais um pedido de estampilha. Ri-se da situação e da solução, mas com tom de crítica. 


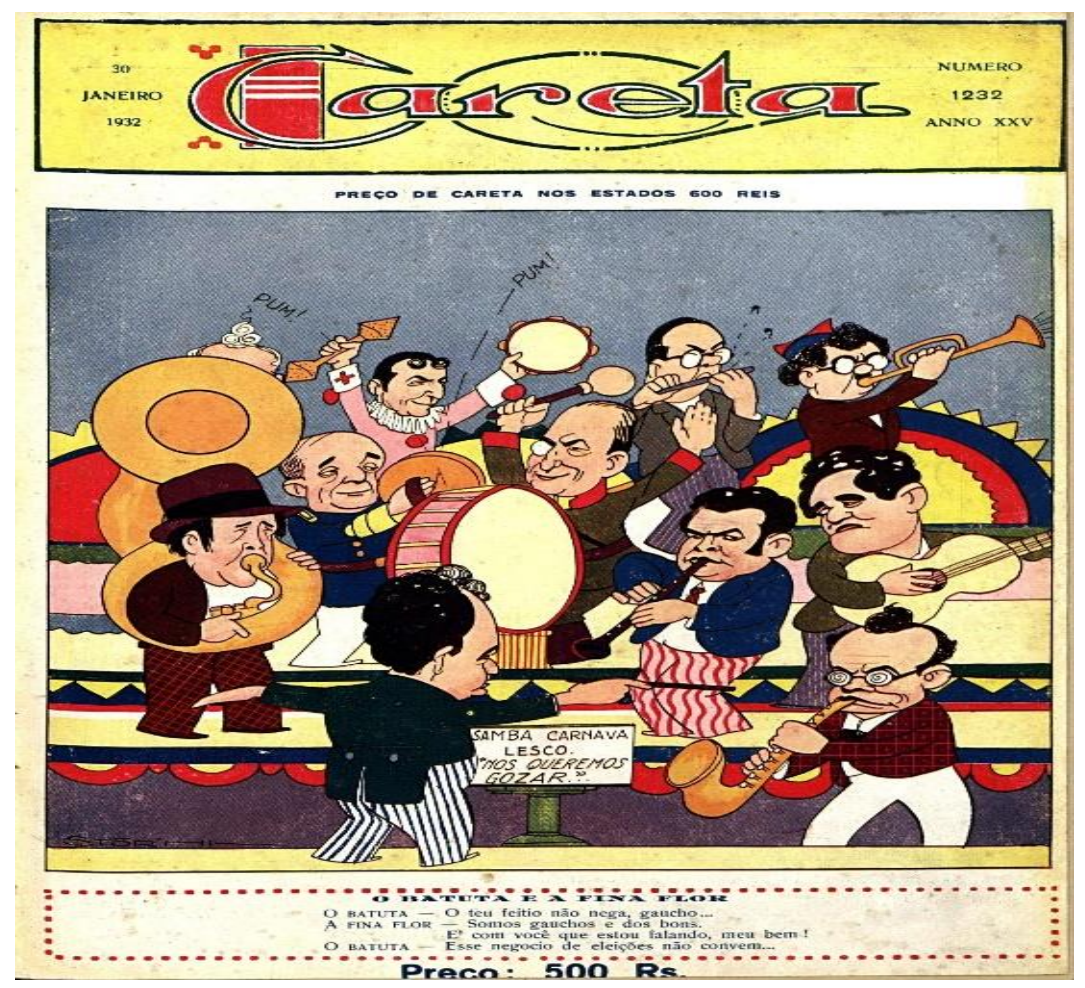

Charge 14

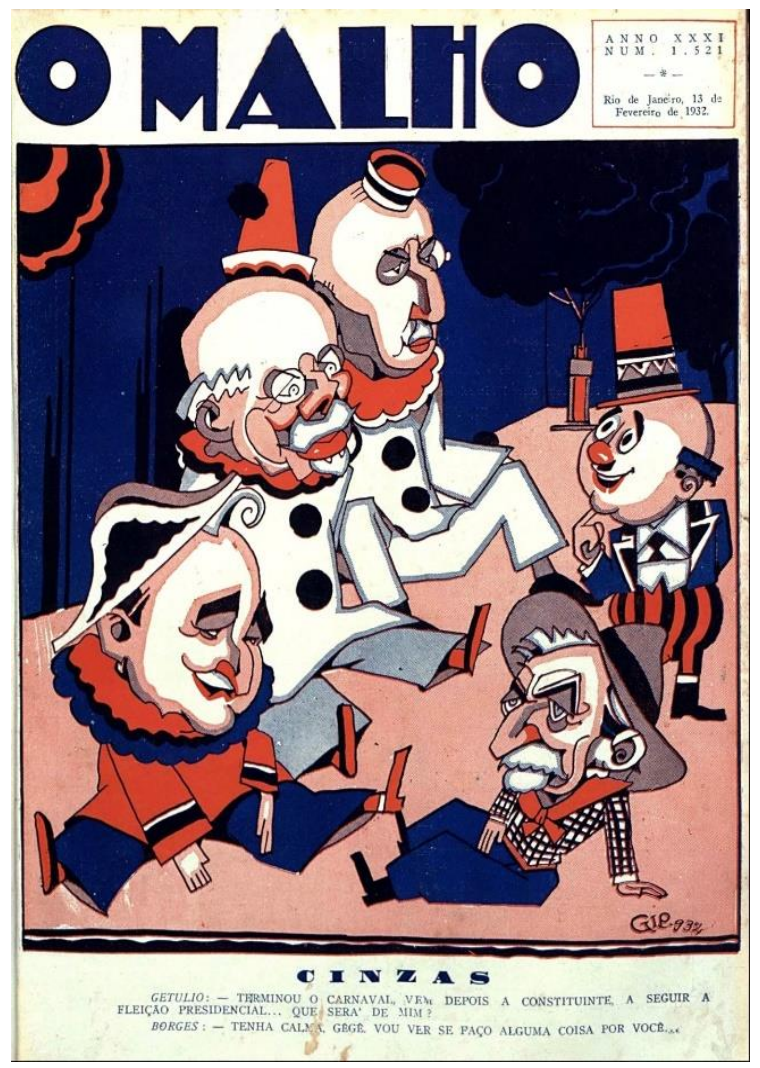

Charge 15

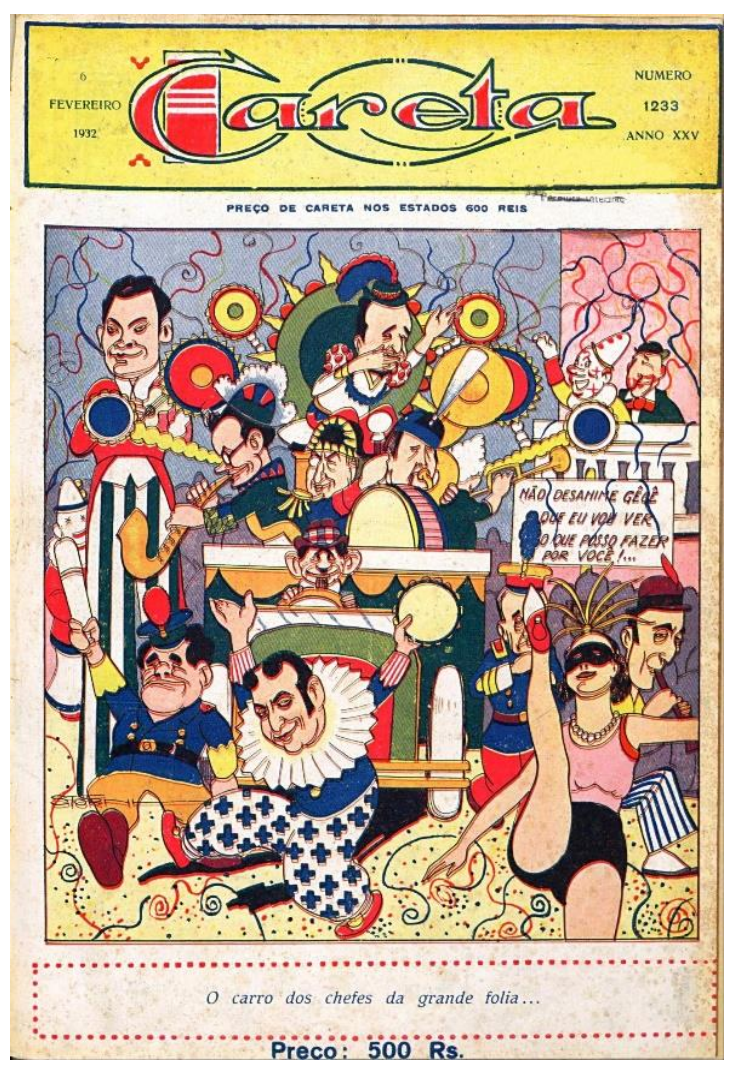

Charge 16

Fronteiras: Revista de História | Dourados, MS | v. 20 | n. 35 |p. 14 - 45 | Jan. / Jun. 2018 
Na charge 14, capa de janeiro de 1932, há uma grande banda regida pelo maestro Vargas. Instrumentos de percussão, sopro e o violão completam o quadro sonoro. O samba executado tem por nome "Nós queremos gozar". O pronome pessoal deve ser dirigido ao maestro e aos músicos (“A Fina Flor”). O dono da batuta canta: "O teu feitio não nega, gaúcho..." e a Fina Flor complementa: "Somos gaúchos e dos bons. É com você que estou falando, meu bem!”. Conclui o batuta: “Esse negócio de eleições não convém...”. O chargista colocou Vargas conduzindo a batuta e os mais proeminentes correligionários políticos da "revolução de 30" como músicos. Qualificou a estes como “a Fina Flor”, com o sentido claramente contrário, ou seja, pejorativo. Trocou palavras das letras de carnaval e, ainda, misturou duas canções. O ano de 1932 foi o ano da luta pelo retorno à normalidade política, e esta se daria por uma nova constituinte (só convocada em 1933). Durante o ano de 1932, diversas charges foram produzidas deixando claro o descompromisso de Vargas com mudanças políticas. Toda a cena é cômica na medida em que coloca importantes membros do governo em situação de inferioridade e cantando música política em ritmo carnavalesco. Clamando pelo restabelecimento da democracia no Brasil, o chargista denuncia o projeto desses elementos em não a promover.

Na capa de O Malho (charge 15), de fevereiro de 1932, vemos a "mascote" (Cardoso) da revista rindo e observando os políticos tradicionais cansados depois de uma intensa batalha (de confete!). Getúlio (com ou sem máscara?), sem fôlego, diz: "Terminou o carnaval, vem depois a constituinte, a seguir a eleição presidencial... que será de mim?”, Borges de Medeiros, seu aliado político, responde: "Tenha calma, Gegê, vou ver se faço alguma coisa por você..." Da mesma forma, a revista Careta desse mesmo mês apresenta em sua capa (charge 16) um grande carro alegórico, com uma banda tocando uma música, sendo seus músicos todos os elementos de proa do governo vigente. Um cartaz, dentro dessa grande festividade, tem escrito: "Não desanime Gegê, que eu vou ver o que posso fazer por você!...”. Uma legenda abaixo explica a imagem: "O carro dos chefes da grande folia..." Destaque para o personagem, a música e a festividade como a unidade das charges apresentadas. Na primeira imagem o carnaval havia passado, na segunda ainda estava sendo realizado. A primeira explica a segunda, depois da folia estavam todos exaustos. A folia da capa de Careta fala de uma grande folia. Seria do carnaval ou da política? Na primeira capa, com o título de "Cinzas" (quarta-feira de cinzas), Vargas disse que acabou o carnaval. As próximas folias seriam diferentes? Afinal, Gegê 
deve trazer o retrato e a estampilha para seus "amigos"? Estes fariam alguma coisa por ele ou prefeririam a Lei Marcial?

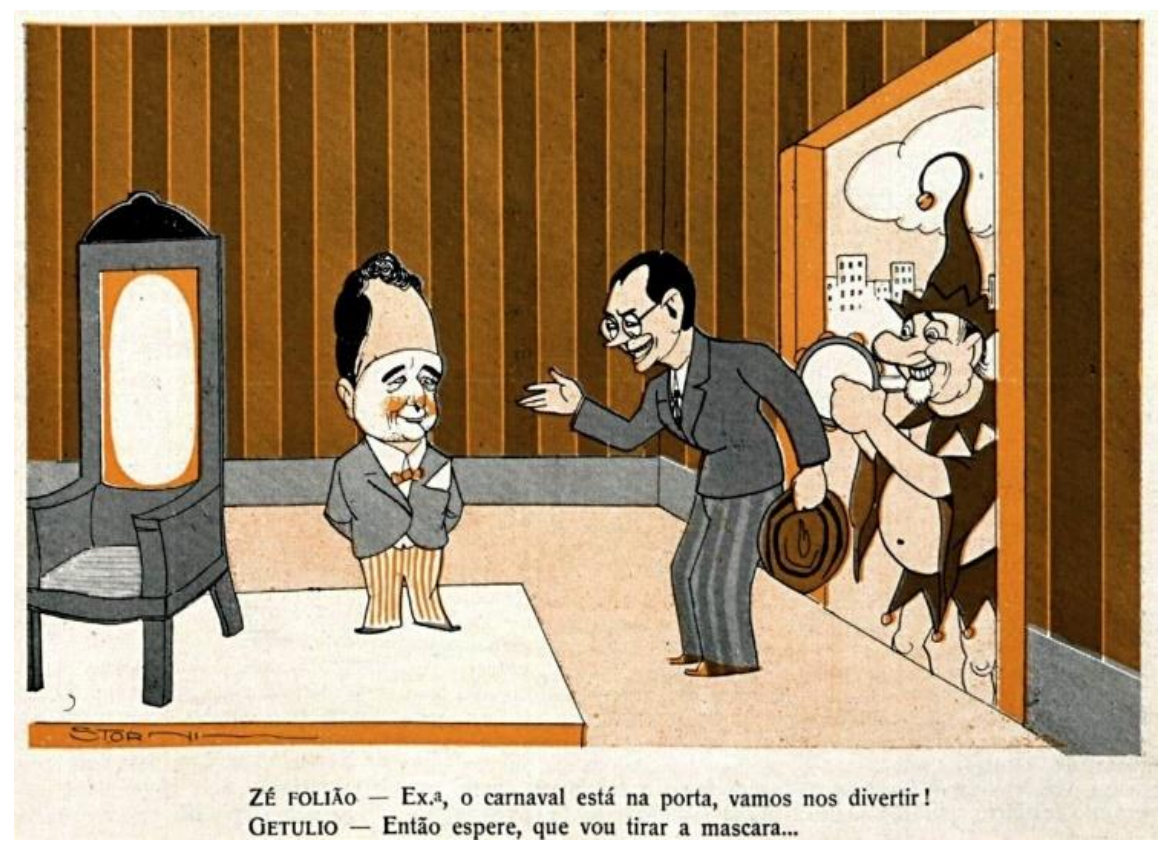

Charge 17

A charge 17 é de janeiro de 1931, ou seja, antes de o carnaval se iniciar. Na porta, um sujeito fantasiado, com máscara e pandeiro na mão. Em um tablado, perto de uma cadeira de espaldar alto (símbolo de poder), está Vargas (lembrando que ele era baixinho) com uma máscara de Vargas, com feição bem feliz. O Zé Folião fala para Vargas: "Excelência, o carnaval está na porta, vamos nos divertir!" Assim responde: "Então espere, que vou tirar a máscara”. Quando todos colocam a máscara, para provocar o riso, para brincar o carnaval com suas fantasias, ocultar de sua identidade, o presidente Getúlio Vargas vai em sentido contrário, ou seja, vai tirar a máscara? Storn mais uma vez trabalha com a dualidade, agora fantasia/realidade; mascarar/desmascarar. Afinal, qual a verdadeira face de Vargas? A máscara, na verdade, é uma metáfora de seu caráter. Qual o verdadeiro caráter de Vargas? Desta vez o leitor está rindo do personagem político, pois é dada a possibilidade de refletir, tomar consciência de quem de fato é Vargas. Lógico que o inimigo irá rir mais, o amigo pode ter uma leitura diferenciada, pois pode vê-lo como uma "raposa política", aquele que consegue 'despistar" seus adversários. Ou não, pode ver a charge sem o motivo para rir, ao criticar seu líder político.

A outra charge (charge 18), capa da revista Careta, de março de 1933, se passa após o carnaval. Todos os personagens ainda de ressaca, com confetes em seus cabelos e nas roupas, Fronteiras: Revista de História | Dourados, MS | v. 20 | n. 35 | p. 14 - 45 | Jan. / Jun. 2018 
com as devidas fantasias depositadas em uma cadeira, são despertados por um cidadão fantasiado de roupas de carnaval, sem nenhum amasso, com uma urna eleitoral sob o braço esquerdo. Este diz; “Acorda, pessoal! O outro carnaval está na porta!...”. Irão os políticos colocar suas fantasias de carnaval ou as fantasias eleitorais? Ao chamar as eleições para a Constituinte de 1933 de carnaval, o fantasiado iguala esta festa festiva, desprovida de seriedade, à festa política, ato coletivo de eleger os representantes do povo para elaborar a mais alta lei de um país. Qualifica o carnaval ou desqualifica as eleições? Evidentemente o riso se torna sério, a charge crítica, critica o fazer eleições no Brasil com os personagens políticos expostos. A dualidade festa/seriedade foi colocada em xeque, tudo se tornou uma festa, mas no caso das eleições, só alguns se divertem e jogam confetes usando suas fantasias.

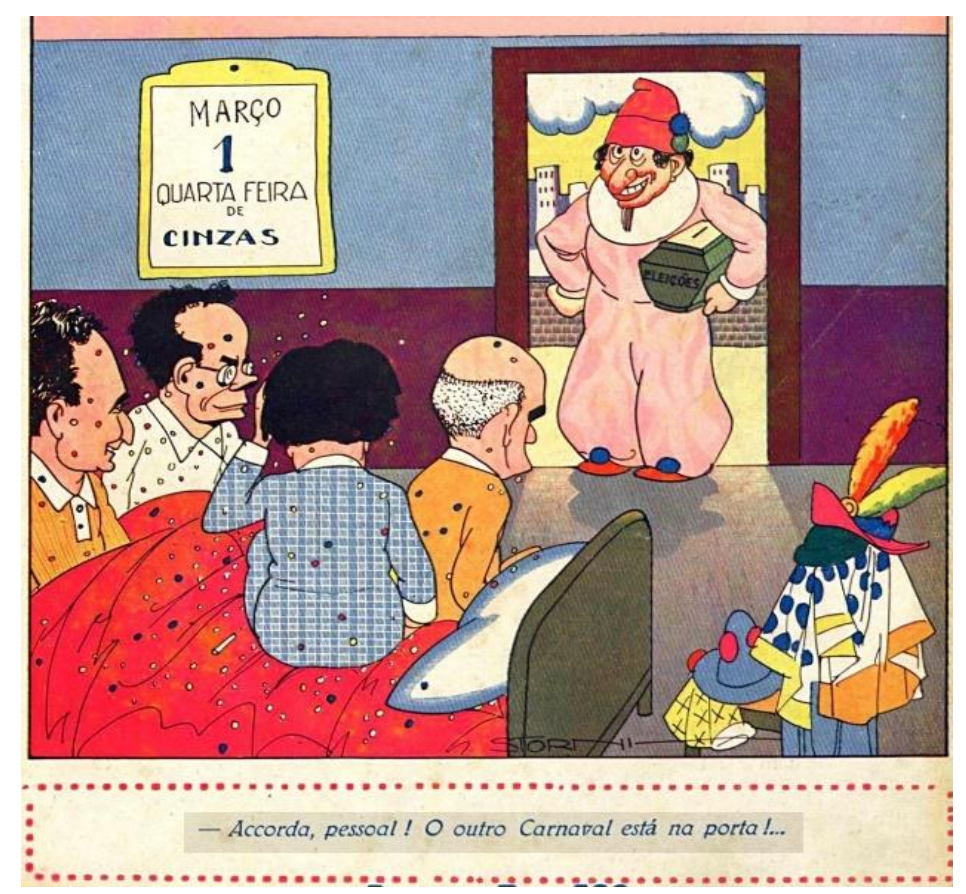

Charge 18

O Malho, em pleno carnaval de 1933, publicou na capa a charge 19 onde ao fundo se vê uma enorme máscara carnavalesca a sorrir, e dois personagens. Vargas, "fantasiado" de presidente, e o Jeca, fantasiado para o carnaval. Vargas diz ao Jeca: "Venha cá, Jeca! Você precisa entrar para o Partido Nacional...”. A figura, que representa o povo brasileiro, responde: “Entrá?! Já tou dentro!... Isso é rancho ou é cordão?!...”. As escolas de samba e seu carnaval na Praça XI não se apresentam nessa charge, apenas o carnaval tradicional composto pelos cordões e pelos ranchos (talvez por isso o Jeca seja branco e sua fantasia exógena). Ao responder que já estava dentro, tendo por dúvida apenas se estava ingressando em um rancho ou cordão, o Fronteiras: Revista de História | Dourados, MS | v. 20 | n. 35 | p. 14 - 45 | Jan. / Jun. 2018 


\section{Fronteiras: Revista de História}

Carnavalização da política ou politização do carnaval: carnaval carioca por meio das charges (1930-1937) Alberto Gawryszewsk

chargista criticou a política brasileira. O riso se instala na inesperada resposta de Jeca, depois no desconhecimento (ou conhecimento) do que seria a política nacional. Seria o Jeca ignorante político ou a política brasileira um carnaval?

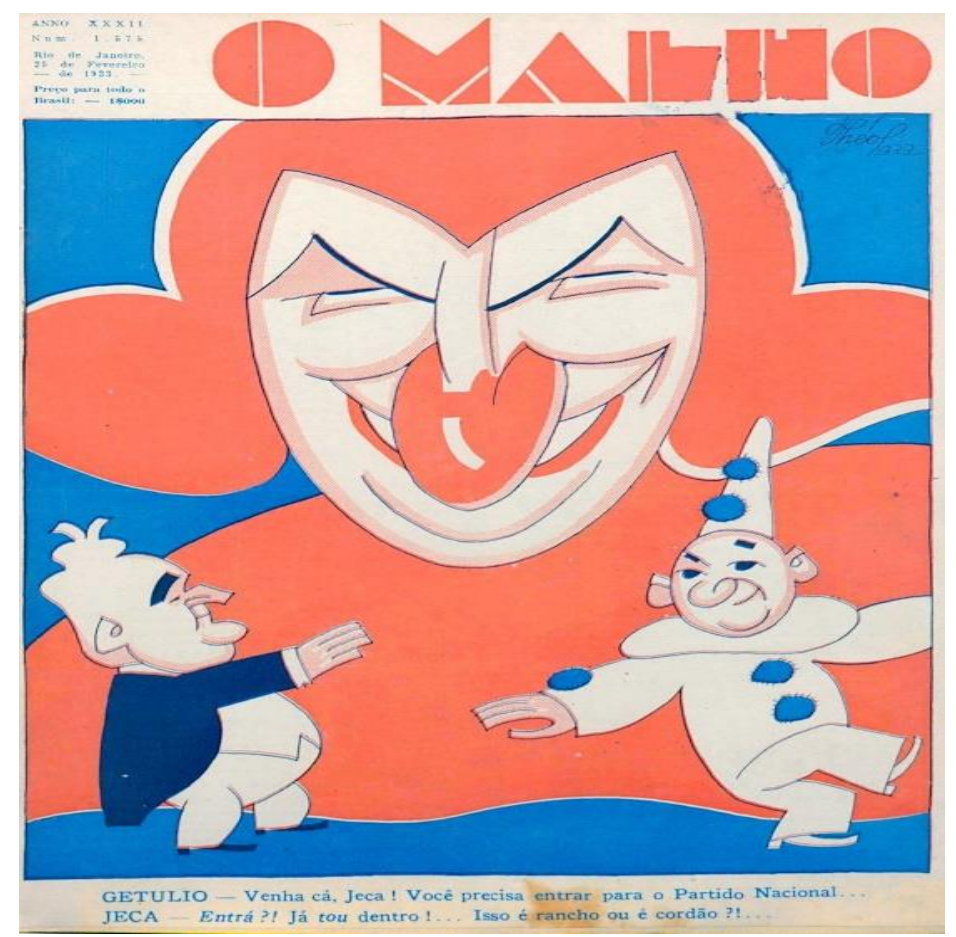

\section{Charge 19}

PANE E CIRCENSIS

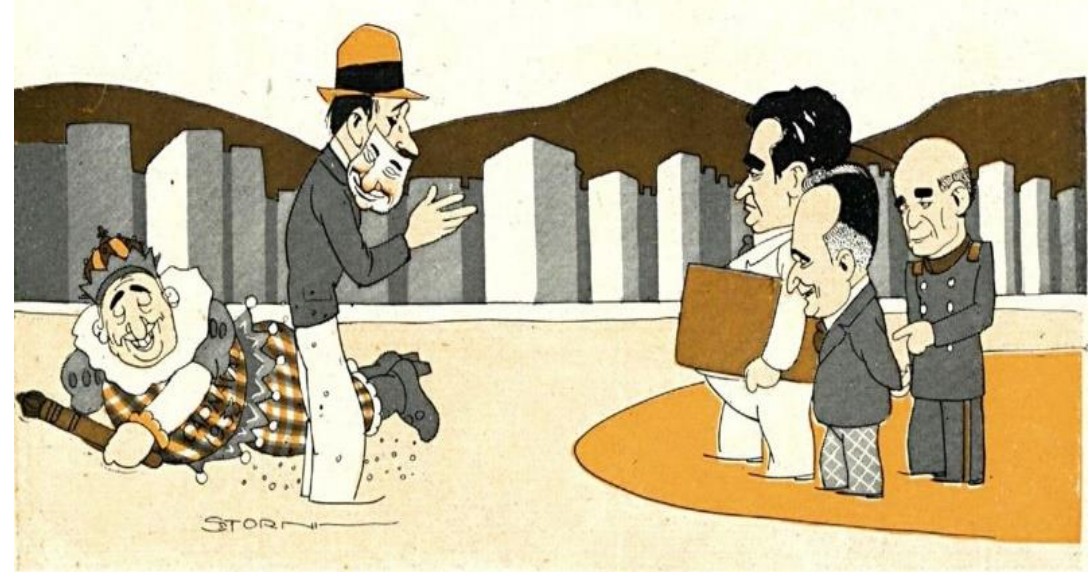

ELLES - 0 que é que você quer ainda?

O CARIOCA - Eu quero mais carnaval senão vou fazer politica !...:

\section{Charge 20}

Fronteiras: Revista de História | Dourados, MS | v. 20 | n. 35 | p. 14 - 45 | Jan. / Jun. 2018 
A charge 20 possui um título sugestivo: "Pane e circenses". O Rei Momo está já caído de cansaço, coberto de confete. O cidadão (o carioca), sem fantasia, apenas a máscara sorridente já descolada do rosto, responde a Vargas e a outros elementos de proa da política nacional: "Eu quero mais carnaval senão vou fazer política!...”. A verdadeira feição do "carioca" parece transparecer ser infeliz, diferente de sua máscara. Vargas, a sorrir (talvez da resposta, talvez de alívio), observa. Afinal, o carioca é um alienado político ou só é feliz no carnaval? Sua ameaça estaria em tornar a política séria ou a política ter participação popular? O riso desconstrói a imagem da política séria de pós-30 e a política de massas. A política de pós-30 ainda não havia sido absorvida pelo "carioca" de forma objetiva e verdadeira. Para onde o Brasil iria após o carnaval?

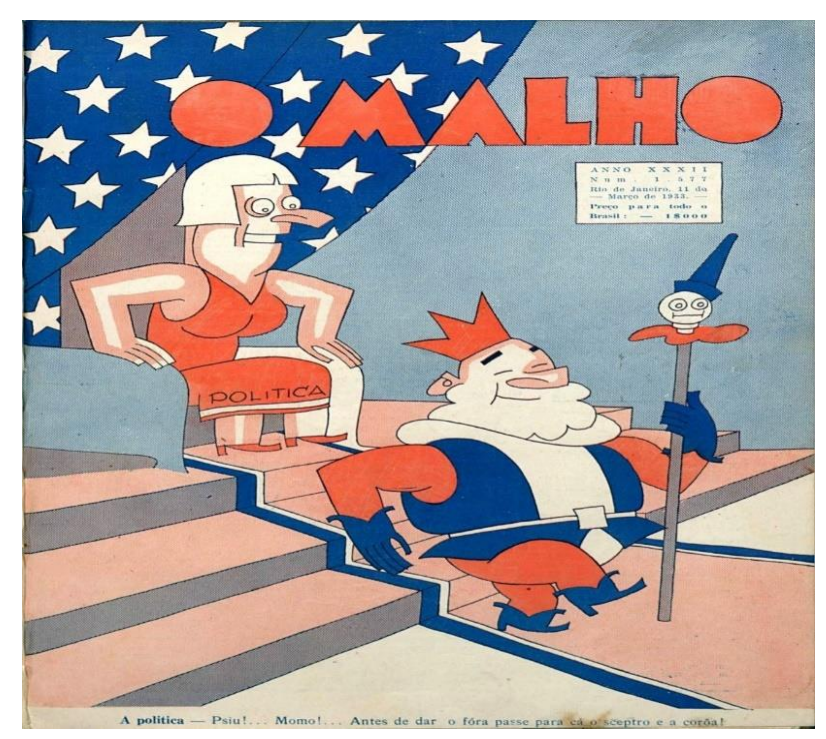

Charge 21

$\mathrm{Na}$ charge 21, por fim, se veem estrelas brancas em fundo azul, uma mulher representando a política nacional e o rei Momo feliz, indo embora. "Psiu! Momo! Antes de dar o fora passe para cá o espectro e a coroa", disse a mulher ao outro personagem. O riso é geral, acabou o reinado de Momo. Agora a república assume. Mas, qual a diferença entre os sistemas de governo? Será que o espectro da política também possui uma cabeça de palhaço na ponta ou foi apenas uma adaptação para os dias de carnaval? Sem autoria, essa charge muito bem poderia ser da concorrente Careta, assinada por Storn. Assim, entre as revistas utilizadas aqui como fontes da pesquisa parece haver uma sintonia em relação ao fazer rir, o denunciar, o desqualificar por meio da comparação ou similaridade entre os dois eventos "festivos", o carnaval e o fazer política.

Fronteiras: Revista de História | Dourados, MS | v. 20 | n. 35 | p. 14 - 45 | Jan. / Jun. 2018 


\section{NOTAS FINAIS}

A quantidade de imagens disponíveis para análise contendo máscaras, fantasias, carros alegóricos, letras de músicas, temas políticos e carnavalescos, problemas urbanos da cidade, conflitos nacionais e internacionais, permite um sem fim de possibilidades de recortes.

O riso para uns pode ser a tristeza para outros. Quem ri por último ri melhor? Os poderosos riem por último ou riem sempre? O riso e o risível têm seu valor e desvalor, a sua importância, e são perigosos conforme o tempo. Aquilo de que se ri hoje pode ter sido interdito ontem. Ou o contrário. Nesse sentido, qual o papel do carnaval no riso ou deste no carnaval? Perguntas e respostas das mais variadas, sendo as respostas longas e contraditórias conforme o caso. Baudelaire afirma que o risível está em nós, mas no caso deste trabalho fomos nós que produzimos as imagens. Então, o risível está em nós por nós.

Neste trabalho, o carnaval foi o grande pano de fundo para os chargistas de $O$ Malho e Careta produzirem suas críticas ao sistema político vigente, ao estado produzido no pós-30, sobre a participação popular no novo regime. A ditadura criada no pós-Lei de Segurança Nacional e, em especial, com a implantação do Estado Novo (1937-45), fechou as portas para a charge política, a charge crítica. Apenas a charge de costumes continuou permitida, mas sob controle. Mas, mesmo com a censura, Storn e, principalmente, J. Carlos, tendo o carnaval como mote, produziram pelo menos duas charges que desmascaravam o momento ditatorial que o Brasil passava. A charge, no caso deste trabalho, ajudou a compreender não a realidade, mas como duas publicações, com seus artistas, retrataram com sua arte o que o país vivia em termos políticos. O carnaval não estava sempre nas charges, mas a crise econômica, social e política (principalmente) estava quase sempre.

\section{FONTES/PERIÓDICOS}

Revista O Malho - 1930-1937

Revista Careta - 1930-1937

\section{REFERÊNCIAS BIBLIOGRÁFICAS}

ALMEIDA, Paula Cresciulo de. Um samba de várias notas: Estado, imprensa e carnaval no Rio de Janeiro (1932-1935). Mestrado em História. Niterói, Universidade Federal Fluminense, Dissertação de Mestrado, 2013. 
BAKTHIN, Mikhail. A cultura popular na Idade Média e no Renascimento, $2^{\mathrm{a}}$ Ed. São Paulo: Hucitec; Brasília: Edunb, 1993.

BAUDELAIRE, Charles. Escritos sobre a arte. São Paulo: Imaginário. 1998.

CARMONA, Rubén Dário Acevedo. Política y caudillos colombianos en la caricatura editorial (1920-1950). Programa de Doctorado: Universidad de Huelva, Espanha, 2003.

CONNIFF, Michael L. Política urbana no Brasil (Ascensão do populismo - 1925-1945), Rio de Janeiro: Relume Dumará, 2006.

CUNHA, Fabiana Lopes da. Caricaturas Carnavalescas (Carnaval e Humor no Rio de Janeiro através da ótica das revistas ilustradas Fon-Fon! e Careta (1908-1921). Programa de Pósgraduação em História Social. São Paulo: USP. Tese de doutorado, 2008. 2 volumes.

FERREIRA, Fernanda de Moura. A construção axiológica do riso na charge: uma perspectiva Bakhtiniana. Programa de Pós-graduação em Letras, Natal, UFRN, Dissertação de Mestrado, 2013.

FREUD, S. Os chistes e a sua relação com o inconsciente. Rio de Janeiro: Imago, 1996.

GAWRYSZEWSKI, A. Administração Pedro Ernesto (1931-1936). Niterói, Mestrado em História, Universidade Federal Fluminense. Dissertação de Mestrado, 1988.

Conceito de caricatura. "Não tem graça nenhuma." In: Domínios da Imagem. Londrina:

UEL. Volume 2, número 2, 2008. p. 7-26.

Arte visual comunista. Londrina: LEDI/Universidade Estadual de Londrina, 2010.

LIMA, Herman. História da caricatura no Brasil. Rio de Janeiro: José Olímpio, 1963.

MINOIS, G. História do riso e do escárnio. São Paulo: Editora UNESP, 2003.

PROPP, Vladimir. Comicidade e riso. Rio de Janeiro: Ática, 1992.

TENÓRIO, Guilherme Mendes. Zé Povo: humor e política nas páginas de O Malho. Rio de Janeiro: UERJ. Dissertação de Mestrado em História. 2009.

VALE, Rony Petterson Gomes do. O Discurso Humorístico (Um percurso de análise pela linguagem do riso). Belo Horizonte, Faculdade de Letras da UFMG, Tese de Doutorado, 2013.

Recebido em: 02/06/2018 Aprovado em: 02/08/2018 